\title{
Photovoltaic Power Systems Optimization Research Status: A Review of Criteria, Constrains, Models, Techniques, and Software Tools
}

\author{
Samer Alsadi ${ }^{1}(1)$ and Tamer Khatib ${ }^{2, *}$ \\ 1 Department of Electrical Engineering, Palestine Technical University-Khodori, Tulkarm 97300, Palestine; \\ samer_sadi@yahoo.com \\ 2 Department of Energy Engineering, An-Najah National University, Nablus 97300, Palestine \\ * Correspondence: t.khatib@najah.edu; Tel.: +970-59-931-7172
}

Received: 9 September 2018; Accepted: 24 September 2018; Published: 29 September 2018

\begin{abstract}
The photovoltaic (PV) generating system has high potential, since the system is clean, environmental friendly and has secure energy sources. There are two types of PV system, which are grid connected and standalone systems. In the grid connected photovoltaic system (GCPV), $\mathrm{PV}$ generator supplies power to the grid, whether or not the whole or a portion of the generated energy will be used to supply load demands. Meanwhile, the standalone photovoltaic system (SAPV) is used to fulfil a load demand that close to its point of use. These days, many researchers study in term of optimization sizing of photovoltaic system, in order to select optimum number of PV modules, inverter, battery storage capacity, and tilt angle. Based on that, this review aims to give explanations on approaches done by previous researchers in order to find ultimate combinations for design parameters. Moreover, the paper discusses on modelling of PV system components, which includes PV panels' output power estimation and battery system. Finally, simulation softwares that used as sizing tools in previous studies are reviewed and studied.
\end{abstract}

Keywords: photovoltaic; optimum sizing; design; renewable energy; stand alone; grid connected

\section{Introduction}

Rapid reduction of fossil fuel resources and growing evidence of global warming phenomena cause the necessity of urgent search for alternative energy sources. Recent studies shows that renewable energy has great potential and can be used to fulfil world energy demand [1]. According to [2], the PV industry has grown more than $40 \%$ per year since last decades due to rapid decrease in PV technology cost. PV technology may become major alternative energy source in the future since it has several positive attributes, low maintenances, free and inexhaustible energy source and robust and long life time system's components [3]. However, solar energy is not always reliable, because solar radiation varies and frequently changes, due to unpredictable nature and dependence on weather and climate changes. Hence, generated energy does not match with load demand all the time. Energy generated in PV systems depends mainly on solar energy available at the site. Geographical location, ambient temperature, clearness index, tilt and orientation of PV panel are the main factors that affect solar energy collected by a PV panel. Hence, studying these meteorological data is very crucial in preliminary design of a PV system. Other factors may affect energy generated, such as shading effect, cable reduction factor, system elements and configurations losses.

There are two types of PV power systems namely grid connected and standalone systems. Grid connected photovoltaic (GCPV) systems engage PV technology with electricity grid network. In the GCPV system, an inverter converts DC electricity generated by PV modules into AC electricity. 
Then, output power from inverter is fed to the utility grid [4]. On the other hand, standalone photovoltaic (SAPV) systems are off grid systems, where PV technology is not connected to the grid, and power generated is not sold to the utility [5]. Before recommending and installing a PV system, it is crucial to ensure that the system is not over/under sized. In other words, the designer has to investigate the viability of system carefully. To efficiently and economically use solar energy, optimal sizing of the system is necessary so that the proposed system can operate in optimum condition in term of produced units costs and power reliability [6]. Electricity consumption is very important in when it comes to system sizing, as well as economical analysis, since overproduction can affect the feasibility of the system negatively. Thus, large self-consumption is desirable so as to ensure the lowest investment with full use of PV array and/or battery bank.

Some review papers for PV system optimization can be found in the literature. In [7], a review of grid connected PV system in terms of technical and economic aspects was done. Electrical performance of PV modules, energy analysis, potential technical problems, and inverter's role in GCPV was explained exquisitely. However, the authors did discuss the optimization of these systems. In the meanwhile, photovoltaic technology and its power generating capability are reviewed in [8]. The authors discussed different existing PV systems performance and reliability, evaluation models, sizing and control methodologies, grid connection and distribution configurations. However, the authors did not give the major focus to the optimization techniques and constrains. On the other hand, in [9], general discussion for optimization methods applied to renewable energy is presented. However, the PV systems were not given enough focus in this paper. In [10,11], the use of artificial intelligence techniques for PV system optimization is reviewed. The work done in these reviews mainly focuses on the implementation of a specific technique without focusing on the optimization problem itself. Furthermore, in [11], there is no mention of optimization methods for a grid connected photovoltaic system. In [12], a detailed review of the PV system optimization is presented for standalone, hybrid and grid connected systems. However, in this review there is a lack of discussion on available optimization software tools, recent used techniques optimization constrains and systems models. In [13], a review on solar photovoltaic software tools was done. Software's accessibility, prices, working platform, capacities, scopes, resultants and updatability were discussed in this paper. However, the authors did not evaluate the software's limitations, advantages, simulation scopes and what type of system configurations that can be simulated by the software. Meanwhile, in [14], the authors reviewed 19 software tools for hybrid system analysis, with further evaluation on HOMER and RETScreen. Yet, the authors did not mention the software's cost and availability.

Based on that, this review aims to give explanations on approaches done by previous researchers in order to find ultimate combinations for design parameters. Moreover, the paper discusses on modelling of PV system components, which includes PV panels' output power estimation and battery system. Finally, as none of the aforementioned reviews has discussed the available PV softwares, simulation softwares that used as sizing tools in previous studies are reviewed and studied in this article.

\section{Modelling of PV System's Components}

In a PV system, main and storage energy sources' performance is dependent on each other. Hence, it is important to investigate PV system with and without battery storage system. To predict system performance, each component needs to be modelled first and then the combination can be evaluated whether it meets the design objectives or not. As a fact, if power output prediction is accurate enough, the resultant combination will deliver power with least cost.

\subsection{Modelling of Photovoltaic Panel}

The accuracy of a PV model has a great significance on system design. To predict the energy output of the system, researchers have to investigate meteorological condition at system's location. It is because the performance of PV modules strongly depends on the sun light condition and cell 
temperature. Moreover, the energy generated also depends on components' rated characteristics, installation configuration, and surroundings' condition [7].

PV power generated from a PV panel is highly affected by total of solar radiation received. Solar radiation data provides information on how much energy strikes the specific earth location [15]. However, solar radiation value is different if the panel slanted at different angles and orientations. Solar radiation data often measured in horizontal plane without any obstacle or shading effect. However, in some situations, when PV panels are mounted in tilted position, such as in building integrated photovoltaic system application, the total radiation input for the tilted PV modules has to be calculated [3]. Following this, Khatib T. et al. reviewed solar energy modelling techniques in [15]. The authors presented linear, nonlinear and artificial intelligence approach models for both global and diffused solar energy model on horizontal PV panel. The direct solar radiation comes directly from the sun. Meanwhile, diffuse solar radiation scattered from dome of the sky without direction. However, for a tilted PV panel, solar radiation comprises direct portion, diffuse portion and reflected portion [15-17]. To model diffused radiation on a tilt surface, isotropic and anisotropic models can be used [15]. According to [18], the isotropic model assumes the intensity of sky-diffused radiation is uniform over the sky dome. Hence, the diffuse radiation incident on a tilted PV module depends on the fraction of the sky dome seen by it. The second model is the anisotropic model, where it assumes the anisotropy of sky diffused radiation in circumsolar region and isotropic distributed diffuse component from the rest of sky dome.

The output power of a PV system is accessed via voltage and current produced from PV module where the multiplication of voltage and current produces power [19]. However, it is important to analyze power estimation accuracy, since the actual power output is usually lower than modelled one [5]. In [20], the author reviewed methods to calculate annual photovoltaic generation, by sorting all of the proposed methods into three categories. In the first method, the authors construct an I-V curve by using atmospheric parameter value, and power generated was calculated from it. Meanwhile, in the second method the power is directly calculated using time series atmospheric parameter values. On the other hand, the last method employs some technical factors such as performance ratio and system efficiency in calculating the power generated from a PV panel/array. In [1], the authors conduct a simple review on classical and novel modelling techniques applied for various types of photovoltaic systems such as meteorological data forecasting using artificial intelligence techniques.

In general, two circuit diagrams can represent PV cell model namely single-diode and two-diode models. Single diode model is one of the most commonly used PV generator's models. Both models are based on the fact that the solar cell is an illuminated p-n junction in the reverse-bias, connected to a resistive load. From [21], a solar cell can be represented using an equivalent circuit diagram consisted of a dependent current source connected on parallel with diode in the reverse mode. These two components are also connected in parallel with a relatively large resistor to represent the dark current of this p-n junction. In addition to that a resistance is connected in series to the aforementioned components so as to represents the internal resistance of the solar cell (see Figure 1), where $I_{P H}$ is light generated current $(A), D$ is diode, $I_{D}$ is diode current due to the p-n junction under forward bias $(A)$, $R_{S}$ is series resistor $(\Omega)$, and $R_{S H}$ is shunt resistors $(\Omega)$. The general I-V characteristic of a PV panel based on the single exponential model is:

$$
i=I_{P H}-I_{O}\left(e^{\frac{v+i R_{S}}{n_{S} V_{t}}}-1\right)-\frac{v+i R_{S}}{R_{S H}}
$$

where $I_{O}$ is dark saturation current in STC, $A$ is diode quality (ideality) factor, $k$ is Boltzmann's constant, $q$ is electron charge, $n_{s}$ is number of cells in series, and $T_{s c}$ is temperature at STC. $V_{t}$ is the thermal voltage and it can be given by,

$$
V_{t}=\frac{A k T_{\text {stc }}}{q}
$$




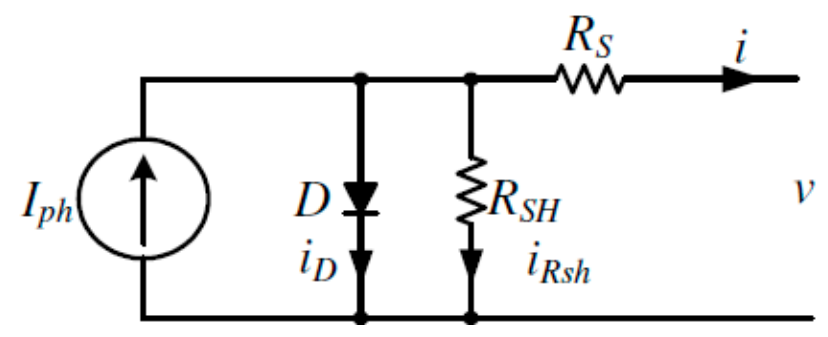

Figure 1. Electrical Equivalent of PV Cell on one-diode model [21].

On the other hand a diagram of a solar cell model using two diodes can be the same as Figure 1 but with additional diode in the parallel to the first diode. The general I-V characteristic of a PV panel based on the two diodes model can be described as,

$$
i=I_{P H}-I_{O 1}\left(e^{\frac{v+i R_{s}}{m_{1} V_{t}}}-1\right)-I_{O 2}\left(e^{\frac{v+i R_{s}}{m_{1} v_{t}}}-1\right)-e^{\frac{v+i R_{s}}{R_{P}}}
$$

However, one of the most important methods used to predict power generated from a photovoltaic panel is using current-voltage characteristic. Some researchers used maximum output power of the PV module to forecast PV system performance, calculated using datasheet's specification under standard test condition (STC). The calculation of maximum power output of a solar cell can be done by,

$$
P_{m p \_s t c}=V_{o c} I_{s c} F F
$$

where $P_{m p \_s t c}$ is maximum output power of solar cell $(W), V_{o c}$ is solar cell open circuit voltage $(V)$, $I_{s c}$ is short circuit current of solar cell $(A)$ and $F F$ is fill factor [22]. $F F$ is a term to show how much energy can be extracted from the module, and calculated as:

$$
F F=\frac{P_{m p}}{V_{o c} I_{s c}}=\frac{I_{m p} V_{m p}}{V_{o c} I_{s c}}
$$

Then, the mathematical model to estimate instantaneous PV module power output under real operating condition in term of $P_{m p \_s t c}$ can be represented by following expression [5]:

$$
P_{p v}(t)=\eta P_{m p \_s t c} P S F
$$

where PSF is peak sun factor (dimensionless) and $\eta$ is de-rating factor. PSF was calculated using following expression:

$$
P S F=\frac{G_{\text {array_plane }}}{G_{\text {stc }}}
$$

where $G_{\text {array_plane }}$ is the irradiance measured in array plane, and $G_{s t c}$ is solar irradiance under standard test condition $\left(1000 \mathrm{Wm}^{-2}\right)$.

Meanwhile, the mathematical model of a solar cell power output at time $t$ is:

$$
P_{p v}(t)=V_{p v}(t) I_{p v}(t)
$$

where $P_{p v}$ is output power of solar cell $(W), V_{p v}$ is solar cell operating voltage $(V)$, and $I_{p v}$ is output current of solar cell $(A)$ [23].

In some researches, several authors foresee energy output performance instead of power prediction in their design. As in [24], the authors use energy produced by PV array, $E_{p v}$ in term of derating factors, $\eta$, area, $A\left(\mathrm{~m}^{2}\right)$ and solar energy, $E_{S u n}$ as follows,

$$
E_{P V}(t)=E_{\text {Sun }}(t) \eta A
$$


Moreover, some authors prefer to use energy yield as indicator for system performance. Energy yield in a period of interest can be calculated using equation [25]:

$$
E_{P V}=P_{m p \_s t c} \eta P S H
$$

where $P S H$ is peak sun hour at specified tilt angle over a period (h). Here PSH at specific tilt angle means the number of hours that a PV panel that is slanted at a specific tilt angle can receive $1000 \mathrm{~W} / \mathrm{m}^{2}$. This mean that the maximum total energy yield that can be provided by a PV panel at a specific tilt angle.

In [26], Mellit A. et al. proposed a model for photovoltaic system using adaptive artificial neural network, that combines Levenberg-Marquardt algorithm (LM) as learning algorithm and infinite impulse response (IIR) filter to accelerate convergence of the network [26]. SAPV experimental setup at Tahifet, Algeria validated the new proposed model. Solar radiation, ambient temperature and humidity are the simulation's input, and the outputs are voltage and current for photovoltaic generator. From the result, the authors prove that the proposed model is able to simulate different weather condition, and it is possible to generate current used by the load. Later, by using the same experimental setup for PV array area as before in [26], a similar case study with new modelling technique was introduced in [27], using Adaptive Neuro-Fuzzy Interference Scheme (ANFIS). ANFIS is a method that applies learning techniques in neural network and fuzzy inferences system, where the method can exploit both data and knowledge. From global radiation, ambient temperature and clearness index as an input, voltage and current for photovoltaic generator was generated. The result was proven to have reasonable accuracy compared to measured data, and more accurate compared to ANN model.

As mentioned before, the real energy yield is always lower than theoretical energy production, due to power derating factor, $\eta$ such as losses caused by dirt, shading, mismatch factor, mounting condition, manufacture tolerance, cable loss, aging and inverter efficiency. Most models correlate de-rating factor with ambient temperature. Most studies calculate temperature losses factor using the following equation,

$$
f_{\text {temp }}=1+\left[\gamma_{\text {pmp }}\left(T_{\text {cell }}-T_{\text {STC }}\right)\right]
$$

where $\gamma_{p m p}$ is power coefficient $\left(\% / C^{-1}\right), T_{c e l l}$ is temperature measured from the back of the module, and $T_{S T C}$ is temperature in standard test condition [4].

\subsection{Modelling of Battery System}

Energy storage is needed to supply load when a SAPV generates energy that is not sufficient to supply a load demand, and to store surplus power when there is excess energy generated by the system. For photovoltaic systems, there are three storage medium can be used, which is battery, fuel cell and supercapacitor. The storage medium is very important as an energy source, during low radiation in night or during autonomy days [28]. The most widely used storage technology in standalone PV systems is a lead acid battery, since it has high system reliability and long time services. However, lead acid battery may be damaged by poor charging control, which may cause overcharging or under-discharging [29].

One of the most earliest battery models in a PV system was presented in [30]. The researchers modelled the battery system based on its behaviour during charging and discharging. The behaviour is described as state of charge (SOC) as follows,

$$
\operatorname{SOC}(t)=\operatorname{SOC}(t-1) \sigma+I_{b}(t) \Delta t \eta_{b}
$$

where $\sigma$ is self-discharge rate, $I_{b}$ is battery current (charge during positive and discharge during negative), and $\eta$ is battery efficiency.

In recent years, most studies for system planning and sizing used different expression of SOC. In low solar radiation intensity, load demand can be met if the battery has not reached the maximum 
allowable depth of discharge. Simple mathematical model for battery's state of charge at time $t$ is represented by following equation [31,32],

$$
\operatorname{SOC}(t)=\operatorname{SOC}(t-1)+\left[\frac{N_{p v} P_{p v}(t)-P_{\text {load }}(t)}{V_{b} * C_{b}}\right]
$$

where $N_{p v}$ is number of PV module, $P_{l o a d}$ is electric power demand $(W), V_{b}$ is battery voltage $(V)$, and $C_{b}$ is capacity of battery bank (Ah). This model ignores charging, discharging and self-discharging efficiencies. In [33-35], a more detailed model was used. In each time step, charging and discharging efficiencies were applied in calculation.

In addition to that, energy management for standalone PV-Battery-Diesel was done in [36], exclusively for a configuration where battery and diesel generators are centralized, and PV and loads are distributed. In the proposed strategy, there are three different mode operations, which are normal operation, PV power limitation, and diesel generator. During normal operation, diesel generator is not connected, and the PV array supplies the load demand and battery is either charged or discharged subject to demanded energy. While in the second mode where battery is fully charged, a new strategy to limit distributed PV generation is presented by a controller scheme to avoid being overcharged or over-currents. When power limitation is necessary, a battery inverter will increase the frequency, and then PV inverters detect frequency increment, it will reduce their generated power. The system will operates in third mode, in case when PV generated power is not enough to supply demand and battery SOC is lower than its' lowest limit. Hence, PV and diesel generator will supply demands and charge battery, until fully charged. In this research different expression for battery state of charge was used. The SOC was determined by,

$$
\operatorname{SOC}(t)=\operatorname{SOC}(t-1)+\left[\frac{\int I_{b} \eta_{b} d t}{C_{b}}\right]
$$

Meanwhile, in [37], for standalone PV system, the authors estimated battery's energy flow as in equation below,

$$
E_{B}(t)=\left\{\begin{array}{c}
E_{B}(t-1) \eta_{\text {inv }} \eta_{\text {wire }} \eta_{\text {discharging }}-E_{L}(t) E_{D}<0(\text { discharge }) \\
E_{B}(t-1) \eta_{\text {charging }}+E_{p v}(t) E_{D}>0(\text { charge }) \\
E_{B}(t-1) E_{D}=0
\end{array}\right.
$$

where

$$
E_{D}(t)=E_{p v}(t)-E_{L}(t)
$$

$\eta$ is derating factor, $E_{B}$ is energy stored in battery, $E_{P V}$ is energy generated from PV generation system, $E_{L}$ is energy demand, and $E_{D}$ is energy difference between $E_{P V}$ and $E_{L}$. Energy stored in battery is depend on inverter efficiency, cable losses, battery's charging and discharging efficiency, load demand and energy generated from PV system.

Besides that, there are several other methods that can be used to model a battery system. A simulation model for grid tied residential PV battery system was done in [38], and evaluated using energy assessment criteria. The authors modelled their battery system using AC coupled battery system layout, multi-crystalline PV module technologies and lithium-based battery system. Energy assessment criteria, in term of self-consumption rate, $s$ and self-sufficiency, $d$ of battery were evaluated, using the following equations,

$$
\begin{aligned}
& s=\frac{E_{D U}+E_{B C}}{E_{P V}} \\
& d=\frac{E_{D U}+E_{B D}}{E_{L}}
\end{aligned}
$$


where $E_{D U}$ is energy directly used by load, $E_{B C}$ is energy to charge battery, $E_{B D}$ is energy discharged by battery, $E_{P V}$ is energy generated by PV panel, and $E_{L}$ is load demand. Energy assessment is important to monitor battery usage, in order to prevent energy saturation. However, in this battery model the authors neglect several factors that affect a battery's efficiency, like self-discharge power, temperature effect and battery age. Besides, there is no explanation for the method to model PV generated power, valuation of battery's state of charge, and energy provided from/to grid.

Another study for optimization of battery capacity in GCPV was done, by considering battery's operation scheduling and ageing effect on economic analysis [39]. Discrete dynamic equation for battery in day's time step, $(i, t)$, can be given as,

$$
\frac{E_{B}(i, t)-E_{B}(i, t-\Delta t)}{\Delta t}=P_{B d c}(i, t)
$$

where $P_{B d c}$ is power stored in battery, $E_{B}$ is energy stored in battery, and $t$ is time. If $P_{B d c}>0$, it is charging since energy stored in battery is increase, and vice versa. Power feed to AC bus from battery supply, $P_{B a c}$ is given by,

$$
P_{B a c}(i, t)=\left\{\begin{array}{c}
\eta_{B i} P_{B d c}(i, t), \text { if } P_{B d c}(i, t)<0 \\
\frac{P_{B d c}(i, t)}{\eta_{B i}} \text { otherwise }
\end{array}\right.
$$

where $\eta_{B i}$ is battery bidirectional converter's efficiency. Besides that, the equation for battery's ageing model is described as,

$$
\Delta C(i, t)=\left\{\begin{array}{c}
\Delta C(i, t-\Delta t)-Z \frac{P_{B a c}(i, t)}{\eta_{B}} \Delta t, \text { if } P_{B a c}(i, t)<0 \\
\Delta C(i, t-\Delta t), \text { if } P_{B a c}(i, t)>0
\end{array}\right.
$$

where $C$ is usable battery capacity, $\eta_{B}$ is conversion capacity of battery, and $Z$ is ageing coefficient.

A study to compare two type of storage types for grid tied PV generation application, which are lead acid storage and hydrogen storage model are simulated in [40]. Equation (21) below represent voltage of lead acid battery, $V_{b}$, where battery current, $I_{b}$ is positive during charging, negative during discharge, $R$ is internal resistance, and $V_{o}$ is equilibrium voltage.

$$
V_{b}=V_{o}+R I_{b}
$$

Meanwhile, in [41], the authors proven that CIEMAT (Copetti) model is able to present dynamic and complex lead acid battery operation. In this paper, the Copetti battery model was simulated and compared with two experimental PV system models. The model was presented by discharge, charge and overcharge process. However, the result was slightly over approximated charging.

A model of PV pumping system, including PV array, battery and electric motor were modelled in $[42,43]$. However, instead of using state of charge, the authors implemented state of voltage (SOV) to model the battery system. It is because, since battery's state of charge is dependent on voltage. In SOV calculation, battery voltage, $V_{b}$ was estimated using the expression below,

$$
V_{b}=V_{o}+K_{e} \ln \left[1-\frac{Q}{C * I_{b}}\right]+R_{b} I_{b}
$$

where $V_{o}$ is a constant that represents battery voltage at initial condition, $C^{*} I_{b}$ is battery capacity as a function of current, coefficient $K_{e}$ is model parameter, $Q$ is exchanged electric charge, $R_{b}$ is battery's internal resistor, and $I_{b}$ is battery's current, where $I_{b}>0$ during charge and $I_{b}<0$ during discharge. Expression of $Q$ is calculated using basic charge equation as below:

$$
\frac{d Q}{d t}=\left|I_{b}\right|
$$


A modified battery ageing model, based on Shepherd's initial model was developed in [44], by predicting the temporal variation, and controlling deterioration of battery parameters and performance [44]. In this paper, the authors predicted charge and discharge operation using correlation of voltage, current and battery state of charge. During discharge, battery's current is lower than zero, and vice versa during charging. Both Equations (25) and (26) represent battery output voltage at each time step, $U(t)$ during discharge and charging process. Coefficient $g$ is the coefficient with characterise $\Delta U=f(Q), R$ is internal resistance, $I$ is current, $t$ is time, $T$ is temperature, $M$ is slope of $U=f(t, I, Q)$ characteristic, and $c$ and $d$ represent charge and discharge.

$$
\begin{gathered}
U(t)=U_{d}-g_{d} \frac{I t}{C}+R_{d} I\left[1+\frac{M_{d} I t}{C\left(1+C_{d}\right)-I_{t}}\right] \\
U(t)=U_{c}-g_{c}\left(1-\frac{I t}{C}\right)+R_{c} I\left[1+\frac{M_{d} I t}{C * C_{c}-I_{t}}\right]
\end{gathered}
$$

\section{Available Photovoltaic Software}

In fact, it is crucial to predict system's performance in a given location and expected operation condition. Moreover, system size must be determined in early stage of planning and designing. System performance modelling tools and computer simulations can be useful to designers or system integrators to predict energy output, as well as analyzing possible configuration $[45,46]$. Nowadays, variable of software tools exist to analyze, simulate, and design PV system. Most of the systems involve solar radiation estimation, while taking account of characteristic and location of PV system. The simulation software may expedite overall design process, compared to sizing intuitively using manual calculation.

There are five categories of software application, which are simulation tools, economic evaluation tools, analysis and planning tools, site analysis tools and solar radiation maps, as shown in Figure 2. In simulation, economic evaluation, and analysis and planning tools, the software divided into two categories, which is exclusively on PV system only, and simulation on hybrid technology options.

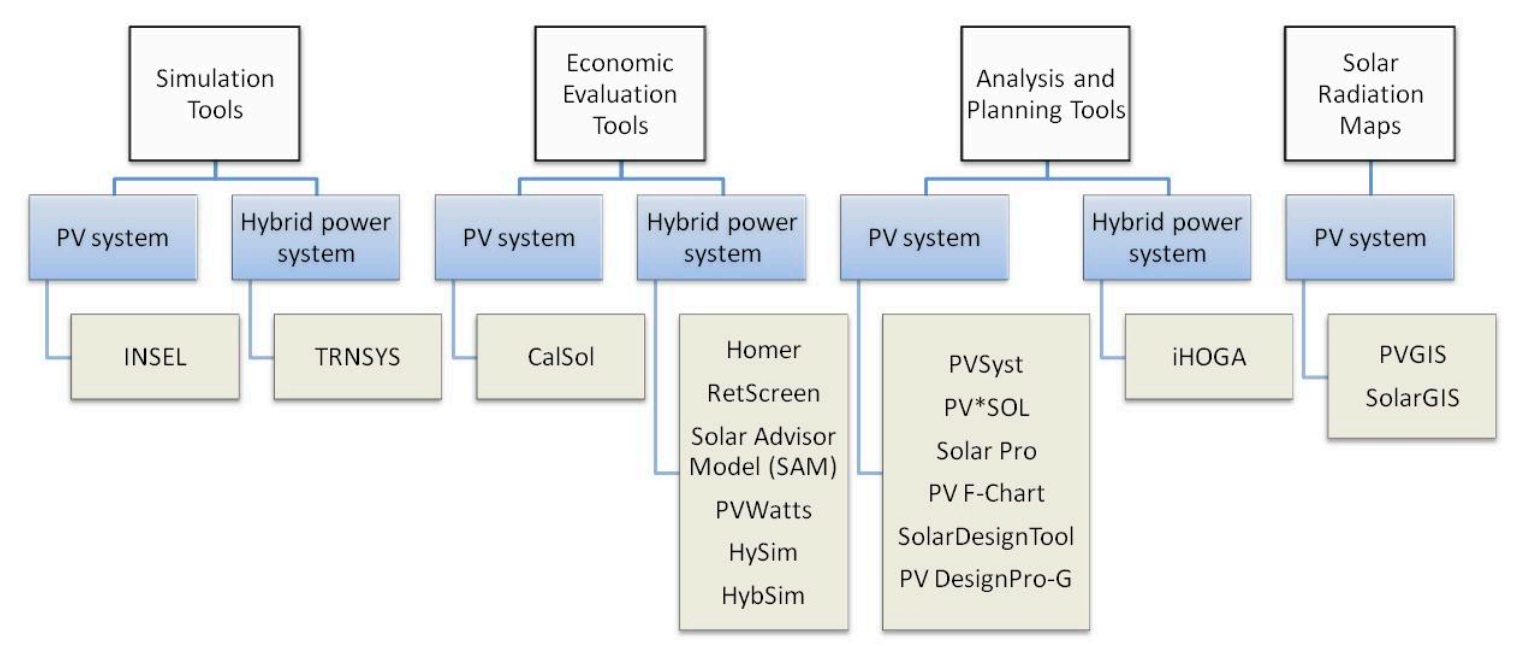

Figure 2. Classification of simulation software based on its application.

\subsection{PV System Simulation Tools}

Simulation tools are software programmed to simulate or predict power system performances as designed by users, using the best meteorological algorithm and/or collected meteorological database. The software were developed to simulate, analyze, monitor and visualize power system performances, but unable to optimize the system. 
Integrated Simulation Environment Language (INSEL) is simulation software developed by the University of Oldenburg, Germany. INSEL is able to create system model and configurations for planning and monitoring electrical and thermal system. This software is suitable to simulate time series solar irradiance, PV power plant, solar cooling and heating system. The user will construct the proposed power system configuration by connecting blocks provided in the library. The advantage of this software is that it provides PV components database, such as PV modules, inverters, and thermal collectors. Besides, the software is also able to detect faults in the system. It is said that the software able to solve any computer simulation problem. The software has meteorological database from 2000 locations worldwide, and it can generate hourly irradiance, temperature, humidity and wind speed. The output consist graphical and numerical output. Price for full version software is 1700 euro and 85 euro for student. Trial version for this software is free and available in the website $[13,47,48]$.

Another simulation tool available is Transient System Simulation (TRNSYS), which was developed by the University of Wisconsin, Madison, USA. Compared to INSEL, TRNSYS able to simulate cogeneration power system other than PV system and thermal system, including wind turbine, fuel cells, and batteries. The objectives of the software are to simulate low energy and HVAC system sizing, system analysis, multizone airflow analysis, electrical simulation, solar energy and thermal system design, and control scheme. This software is flexible, where the users able to modify mathematical model in its library. Besides, meteorological data and component designed by users are required as the input in simulation. A demo version for the software is available in its website, and the price for educational use is $\$ 2100[13,14,49]$.

\subsection{Economic Evaluation Tools}

Software that classified as economic evaluation tools is able to provide economic analysis for the proposed system designed by the users. To determine whether the system is feasible or to maximize net benefit of consumption in the electricity services, user need to key in all of the cost and financial parameters as input, and then run the analysis. The analysis is needed to minimize total project costs to meet load demand or project constraints.

One suitable software for simulation and data analysis of PV system is CalSol. The founder of this program is from the Institute National de I'Energie Solaire (INES), France. This software is able to run economic analysis on grid connected, standalone and DC-grid system. Unfortunately, only French meteorological databases are available in this software. Besides, as PVWatts, this software has no PV component database and other programs unable to interconnect with this software. This software is easy to handle, suitable for pre-sizing and it is free, since the software is available via internet $[3,50]$.

The Hybrid Optimization Model for Electrical Renewable (HOMER) is an energy modelling software, developed by National Renewable Energy Laboratory (NREL) USA. The software is suitable to design and analyze hybrid power system, including conventional generators, cogeneration, wind turbines, solar photovoltaic, hydropower, batteries, fuel cells, hydropower, biomass and others. HOMER can provide system optimization and technology options according to cost and energy resources availability. Moreover, this software able to simulate a system for $8760 \mathrm{~h}$ in a year and the results are presented in varies of tables and graphs. The meteorological data for the proposed site can be imported from HOMER energy website or provide specifically by the users. However, since Net Present Cost (NPC) analysis was used in economic analysis, comparison between other power system configurations in term of levelized cost of energy (LCOE) cannot be done. The developer provides a six months free version and then a renewal for 100 USD is required annually. [13,14,48,51]

In addition, RETScreen is also suitable as feasibility study tools for hybrid power generation technologies. Natural Resources Canada develops the software, and it is a Microsoft Excel-based spreadsheet model. The core of the tools consists of standardized and integrated clean energy project analysis that used in worldwide to evaluate energy production, life cycle cost, and green house gas emission reduction for various types of energy efficient and renewable energy technologies. The software also covers on grid and off grid analysis. Beside this, it has a global climate database 
for 6000 ground stations, and it also provides link to NASA climate database. Energy modelling analysis, cost analysis, emission analysis, financial analysis, sensitivity and risk analysis are available in this software. Unlike HOMER, the software can be used to compare levelized cost of energy (LCOE) between other power system configurations. RETScreen is a free of charge software, [13,14,48,52].

System Advisor Model (SAM) is free software, developed by National Renewable Energy Laboratory, Washington. The software is able to analyze all solar technologies, as well as provide intensive financing and cost analysis. The results from the analysis will be presented in term of levelized cost of energy (LCOE), system energy output, peak and annual system efficiency, and hourly system production, in tables and graphs. SAM can automatically download online database, including energy resources for solar, wind, bio fuel, geothermal, US incentives and US utility rates [13,53,54].

PVWatts is automated simple calculator software, it gives quick answer for the expected energy production, and cost saving in grid connected system. PVWatts is a simplified version of PVForm, and it can be used trough SAM or via the Internet. However, PVWatts only allows users to select a location within United States or pre-determined list of locations only. It is also only calculates crystalline-silicon PV modules [55,56].

Hybrid simulation (HybSim) is a hybrid energy simulator developed by Sandia National Laboratory, and suitable to simulate renewable energy such as PV, diesel generators, and battery storage at off grid system. It is able to perform financial analysis such as LCOE, life cycle cost, fuel and O\&M costs, and cost comparison between different configurations. HySim is able to interconnect with other software. For example, HySim used weather and insolation data from TMY2. Unfortunately, it has not been used up until 1996 [14,48].

Meanwhile, hybrid simulation (HybSim) is a hybrid energy simulator developed and copyrighted by Sandia National Laboratory. It is suitable to simulate and analyze life cycle cost and benefit for adding renewable energy at off grid system. It is able to simulate PV, diesel generators, and battery storage. However, at this moment, only PV generation system can be generated, and wind turbine may be added in the future. For weather and insolation, HybSim use measured data for 15-min time intervals. It is able to compare cost and performance between diesel system only and hybrid system with combination of diesel, PV and batteries [14,48].

\subsection{Planning and Analysis Tools}

Planning and analysis tools are suitable to help users in planning, designing, sizing, optimizing sources, and defining proposed system to the highest standard. Some software provides database of PV components available from market to help users design their system in detail.

Due to diligence review in United States, PVsyst is the most commonly used for project development [45]. The founder of PVsyst is a graduate from the University of Geneva, Switzerland. PVsyst is software that able to size, design, simulate and analyze grid connected, standalone and DC-grid connected PV system. Beside Meteo Database existed in the software, this software can also import meteorological data available from web. The software also has a PV-components database that is available in the market. This system also provides variations of parameter settings possibility in the design with high precision result. However, this software does not allow interconnection with other programs. Besides, the sizing is also restricted to collector configuration. There are two types of PVsyst products, which are Pro30 (maximum $30 \mathrm{~kW}$ installation) and Premium. For Pro30 (unlimited installation), the price for first licence is CHF 1000, and CHF 1300 for premium product. While, for second license, the price is CHF 700 and CHF 1000, and for third licence, the price is CHF 500 and CHF 700 for both Pro30 and premium product $[3,48,57,58]$.

$\mathrm{PV} * \mathrm{SOL}$ Expert is a 3D design software for simulates and data analysis of roof-parallel and roof-integrated PV system performances. This software is suitable to plan PV system, from small off grid to large grid connected system. The developer is Solar Design Company from Powys, UK. This software also analyses shading effect on energy performances [13]. Besides, it also gives optimization configuration of PV modules among inverters. PV*SOL objectives include quick design, 
financial analysis and gives suitable proposal. The outputs included yield report, system efficiency, losses and economic reports. Unfortunately, interconnection with another program is not possible [59].

Laplace System Co., Ltd. (Kyoto, Japan), develops SolarPro Japan. Same as PV*SOL Expert, SolarPro is also 3D design software, and able to calculate shading losses. However, this software can only be used to simulate grid connected photovoltaic system only. Its database subsists meteorological from more than 8000 sites and PV components. SolarPro provides output in term of I-V curve, and power generation based on latitudes, longitudes, and weather conditions. Economic analysis in term of life cycle cost is also available in the software. The software price for educational use is $\$ 1900[3,13,60]$.

PV F-Chart is an analysis and design program for PV system, where the company's principals are faculty members at the University of Wisconsin. The software's charge for single user is $\$ 400$, and $\$ 600$ for educational use. The program able to provides monthly average performance estimates hourly for the day. PV F-Chart can simulate system configurations like utility interface system, battery storage system and stand alone, restricted for PV system. Economic analysis is also included in the features, such as buy and sell cost difference, life cycle, initial investment and cash flow analysis. Its database consists of weather data from 300 sites, and can be added by users. The users can set load demand's hourly value for each month, and has statistical load variation. The output was accessible using graphical and numerical, in English and SI unit [48,61].

SolarDesignTool is an online PV design web, that available via the Internet. The software's price is $\$ 7$ for lite series, $\$ 25$ per month for professional series, and the users are able to have 30 days of free trial. It is suitable to simulate PV grid-tied system. This software allows users to design and configure optimal solar system and panel layout. In optimal system design, the software gives several recommendations for possible configurations. Meanwhile, in the system generator, the users also can specifically design their own system configuration, and simulate it. SolarDesignTool has climate database for US and Canada sites. However, the users still allowed to create a reusable custom location. In addition, the software is user friendly, where it can use 3D building model based on aerial and satellite imagery to create preliminary design. Other features available in the software are string configuration for string inverters and distributed MPPT inverter system, branch configuration for micro inverter, automatic optimal panel layout generation and embedded drawing tool to sketch or modify installation area [62].

PV DesignPro-G is able to design and analysis grid connected with no battery storage, from small to large-scale PV system. This software is one of three PV DesignPro included in Solar Design Studio 6.0 CD-Rom, where another two are PV DesignPro-S for stand alone, and PV DesignPro-P for water pumping. The price for the CD-Rom is $\$ 249$. The software able to simulate a predesigned system with preselects climate condition, for one year, on hourly basis. It consist climate database for 239 locations in UA, Alaska, Hawaii, Puerto Rico, and Guam. Besides, the CD-Rom also provides hourly climate generator for 2132 international climates. Other than that, PV panel model was available in database for system simulation. The software also provides Annual Energy Cost analysis and Life Cycle Cost Analysis. The output was presented in tables and various chart [63].

Meanwhile, improved Hybrid Optimization by Genetic Algorithm (iHOGA) is a hybrid system optimization software that suitable to find optimum size of a proposed system. It is a C++-based software, and developed by the University of Zaragoza, Spain. It is suitable to analyze photovoltaic, wind turbine, hydroelectric turbine, fuel cells, $\mathrm{H}_{2}$ tanks, electrolysers, storage system, and fossil fuels, for both stand-alone and grid connected system configurations. Besides, the software is able to simulate four different loads system, which are AC loads, DC loads, Hydrogen loads, and water pumping loads. Its merits are the software use multi or mono objectives optimization using genetic algorithm and sensitivity analysis with low computational time. The features are optimizing the best combination of system components and best control strategies. iHOGA also able to optimize panels slope, life cycle emission, allow probability analysis, and has purchase and selling options for grid connected. iHOGA's education version can be downloaded from the Internet for free. Unfortunately, 
as said in [14], the educational version has demerits, where it can only simulates daily load within $10 \mathrm{kWh}$, and sensitivity analysis, probability analysis, batteries models Coppetti and Schiffer, and net metering is not included. For professional's full version, the cost is $€ 200$ for a license, and for versions with full technical support is $€ 300$ per year [64].

In addition, PV.MY software is a MATLAB-based user friendly software tool called for optimal sizing of photovoltaic (PV) systems. The software is developed by the power research group of the national university of Malaysia. The software has the capabilities of predicting the metrological variables such as solar energy, ambient temperature and wind speed using artificial neural network (ANN), optimizes the PV module/array tilt angle, optimizes the inverter size and calculate optimal capacities of PV array, battery, wind turbine and diesel generator in hybrid PV systems. The ANN-based model for metrological prediction uses four meteorological variables, namely, sun shine ratio, day number and location coordinates. As for PV system sizing, iterative methods are used for determining the optimal sizing of three types of PV systems, which are standalone PV system, hybrid PV/wind system and hybrid PV/diesel generator system. The loss of load probability (LLP) technique is used for optimization in which the energy sources capacities are the variables to be optimized considering very low LLP. As for determining the optimal PV panels tilt angle and inverter size, the Liu and Jordan model for solar energy incident on a tilt surface is used in optimizing the monthly tilt angle, while a model for inverter efficiency curve is used in the optimization of inverter size [65] Finally, The Smart Grid Research group at Lakeside Labs has developed software called RAPS. RAPS is able to simulate a grid connected or standalone microgrid with solar, wind or other renewable energy sources. This software calculates the power generated by each source in the microgrid and then it conducts a power flow analysis. This software is helpful for optimal placement of distributed generation units in a micro grid. The software RAPS is designed for use in science and classroom with a simple to use graphical interface. It is an easy extendable framework that supports users in implementation of their own models, for grid-objects, and algorithms for grid controls [66].

\subsection{Solar Radiation Maps}

Solar radiation maps allow users to understand solar resources for every spot on Earth with a simple visual. There are two software programs available online for this purpose, which are PVGIS and SolarGIS. Both programs provide geographical information based on maps or satellite imaginary. Photovoltaic Geographical Information System (PVGIS) is online software that estimates solar radiation, provides solar radiation maps and calculates annual energy generated from grid connected and standalone PV system. The system was founded in Institute of Energy and Transport-European Commission and it is available on the Internet. This software provides simulation for grid connected PV system only. It is easy to handle, and as PVsyst, it able to import meteorological data. However, this software is exclusively used in Europe and Africa only and has no PV component database. This software also does not include energy de-rating factor and economic analysis. Other than that, no other software could interconnected with this program $[3,67]$. SolarGIS is also a free solar radiation map that is available online. SolarGIS's authors are also the main co-authors for the previous PVGIS. There are six applications for SolarGIS, which is iMaps, estimate energy output, monitor performances for existing power plants, purchase time series of meteorological data, receive real time performance monitoring for solar energy system, and data visualization on poster maps. Its database is a high resolution, and continuously updated on daily basis. The data is generated using in-house developed algorithms [68].

\section{Photovoltaic Systems Optimization Criteria}

To select an optimum combination to meet sizing constraint, it is necessary to evaluate power reliability and system cost analysis for the recommended system. An ideal combination for any PV system is made by the best compromise between two considered objectives, which is power reliability and system cost. 


\subsection{Reliability Analysis}

In PV system design, especially in SAPV system, one of the most important aspects to ensure power system security is to analyze power supply availability. This is because solar energy production in one site is intermittent, and energy generated usually will not match with load demand. A reliable power system is a generation system that has sufficient power to feed load demand in a period. There are many methods to determine reliability of power system. The most popular methods to express system reliability are loss of load probability (LOLP) and loss of power supply probability (LPSP). In both methods, if the probability is 0 , the load then will always be fulfilled, while if the probability is 1 then the load will never be fulfilled.

LOLP is a probability for the case when a load demand exceeds the generated power by the system. Here, the reliable PV system is defined as the system which is able to generate sufficient power $\left(E_{P V}\right)$ to fulfil the demanded load $\left(E_{L}\right)$ within time span. There are several researchers who apply this method in their proposed system's reliability analysis such as [26,69-82]. LOLP can be described as,

$$
\text { LOLP }=\frac{\sum_{i=1}^{8760} \text { Energy Deficit }_{i}}{\sum_{i=1}^{8760} \text { Energy Demand }_{j}}
$$

where,

$$
\text { Energy Deficit }{ }_{i}=\sum_{i=1}^{8760}\left(E_{L}(i)-E_{P V}(i)\right)
$$

On the other hand, LPSP is defined as probability of the case when the system generates insufficient power to satisfy the load demand [83]. LPSP has been used in [84-87] to measure PV system reliability as illustrated below.

$$
\operatorname{LPSP}=\frac{\sum_{i=1}^{8760} \operatorname{LPS}(t)}{\sum_{i=1}^{8760} E_{L}(t)}
$$

where,

$$
\operatorname{LPS}(t)=E_{L}(t)-\left[\left(E_{P V}(t) \eta_{b a t}\right)+E_{B}(t)-E_{B \text { min }}\right] \cdot\left[\eta_{i n v} \eta_{\text {wire }}\right]
$$

There are two approaches for LPSP application in standalone PV design, based on chronological simulation and probabilistic technique. Chronological simulation can present dynamic changing in system performances, for example, energy accumulation effect on battery. Nevertheless, this technique requires time series data in a certain period, and it needs more computational effort, compared to probabilistic technique $[83,86,88,89]$. On the other hand, probabilistic technique eliminates need for time series data and can assess long-term system performances. However, this technique not used in recent studies anymore, as it has a flaw, where researchers cannot observe dynamic changing in system performances.

Some of the researchers will analyze hourly, daily, or monthly energy generated and battery state of charge, by using PV modelling and battery storage modelling as in the previous section. Then, by using the results of energy generated and battery state of charge, reliability analysis within analysis's period, either LOLP or LPSP can be done.

\subsection{System Cost Analysis}

There are several economic analyses used by past researchers in order to find the optimum configuration of proposed system. This criterion was applicable at both GCPV and SAPV system. Economic feasibility analyses that frequently used in past years are Net Present Cost (NPC), Levelized Cost of Energy (LCOE), and Life Cycle Cost (LCC). Economic analysis is worth doing to determine whether the project has or has not acceptable investment. Sometimes, economic analysis was used after reliability analysis, in order to propose a system with high reliability and lowest cost [86]. 
NPC is the total present value of a time series and it was the development of discounter cash flow techniques. The net present worth is found by discounting all cash inflows and outflows, including cost of installation, replacement and maintenance, at an interest rate or internal rate of return (IRR) [90]. NPC can be described as,

$$
\mathrm{NPC}(i)=\sum_{n=0}^{N} \frac{A_{n}}{(1+i)^{n}}
$$

where $A_{n}$ is net flow cash at end of period $n, i$ is IRR, and $n$ is project lifetime.

LCOE $(\$ / \mathrm{kWh})$ defined as the average cost per $\mathrm{kWh}$ of useful electrical energy produced by the system when a lifetime, investment cost, replacement, operation and maintenance, and capital cost is considered [91]. LCOE method was frequently applied in past year's economic feasibility research, since the approach is very useful in comparing different generating technologies with different operating characteristic [6,86]. LCOE is calculated by dividing the produced electricity annualized cost on the total useful electrical energy generated. The mathematical model used to calculate LCOE is as follows,

$$
\mathrm{LCOE}=\frac{\sum_{n=1}^{N} \frac{I_{n}+O_{n}}{(1+r)^{n}}}{\sum_{n=1}^{N} \frac{P_{n}}{(1+r)^{n}}}
$$

where $N$ is economical lifetime of the system, $I_{n}$ is the investment cost in year $n, O_{n}$ is the maintenance and operational cost (O\&M) in year $n, P_{n}$ is the electricity production in year $n$, and $r$ is the discount rate [2].

The third system cost analysis is life cycle cost (LCC). LCC is an estimation for sum of installation cost, operating and maintenance of an item for a period of time, and expressed in today's value [92]. Equation (33) is used to calculate LCC of a PV system,

$$
\mathrm{LCC}=C_{P V}+C_{b a t}+C_{\text {charger }}+C_{i n v}+C_{\text {installation }}+C_{\text {batrep }}+C_{P W O \& M}
$$

where $C_{P V}$ is PV array cost, $C_{\text {bat }}$ is initial cost of batteries, $C_{\text {charger }}$ is cost of charger, $C_{i n v}$ is inverter cost, $C_{\text {installation }}$ is installation cost, $C_{\text {batrep }}$ is battery replacement costs in present value, and $C_{P W O \& M}$ is operation and maintenance cost in present worth. $C_{P W O \& M}$ 's equation is:

$$
C_{P W O \& M}=\left(C_{\frac{\text { O\&M }}{Y}}\right)\left(\frac{1+i}{1+d}\right) \frac{\left[1-\left(\frac{1+i}{1+d}\right)\right]}{\left[1-\left(\frac{1+i}{1+d}\right)^{N}\right]}
$$

Sometimes, some researchers also calculate annual basis expression of life cycle cost (ALCC), with this equation:

$$
\operatorname{ALCC}=\operatorname{LCC} \frac{\left[1-\left(\frac{1+i}{1+d}\right)\right]}{\left[1-\left(\frac{1+i}{1+d}\right)^{N}\right]}
$$

\section{Standalone PV System Optimization Technique}

To recommend an optimum configuration for SAPV system, the designer has to evaluate system design based on optimization variables. As mentioned in [6], as number of optimization variables increase, number of simulation and iteration will exponentially increase, as well as time and effort. Hence, to obtain the best system design as well as simplified sizing process, pioneer researchers introduced several techniques for system sizing calculation. In the SAPV system, there are three major methods which frequently used in former studies namely intuitive method, numerical method, and analytical method [70]. Table 1 shows a summary of merits and demerits of three main optimization techniques for better identification. 
Table 1. Brief comparison on three main optimization techniques.

\begin{tabular}{|c|c|c|}
\hline & Merits & Demerits \\
\hline Intuitive & $\begin{array}{ll}\text { - } & \text { Simple } \\
\text { - } & \text { Did not have to consider random } \\
& \text { nature of solar radiation }\end{array}$ & $\begin{array}{ll}\text { - } & \text { Only suitable for rough estimation } \\
\text { - } & \text { Tend to oversize system } \\
\text { - } & \text { Cannot measure system reliability }\end{array}$ \\
\hline Numerical & $\begin{array}{ll}\text { - } & \text { Frequently used } \\
\text { - } & \text { Adequate analysis can be done } \\
\text { - } & \text { Accurate reliability analysis }\end{array}$ & $\begin{array}{ll}\text { - } & \text { More complex } \\
\text { - } & \text { Need more time for calculation }\end{array}$ \\
\hline Analytical & $\begin{array}{l}\text { - Present relationship between } \\
\text { capacities and reliabilities } \\
\text { - } \quad \text { Sizing task become much simpler }\end{array}$ & $\begin{array}{l}\text { - The relation cannot be applied at } \\
\text { different sites } \\
\text { - Had error function compared to } \\
\text { numerical calculation }\end{array}$ \\
\hline
\end{tabular}

\subsection{Intuitive Methods}

The intuitive method is simple, easy to be implemented, and can be used to give rough suggestion for preliminary design. The sizing rules are base on designer's experience, using lowest performance either in a time period data or by directly using average value (daily, monthly, or annual) of solar irradiance. Hence, this method allocates the system to generate more power than required by a safety margins. The quantitative relationship between subsystem, such as generated power subsystem, battery's state of charge subsystem, or reliability subsystem, is not considered. Besides, this technique also does not consider random nature of solar radiation and meteorological condition. This method is not very popular because it is limited for rough estimation and preliminary design only. Besides, this method tends to give oversized design and has low reliability [12,34,79].

There are some studies for optimal sizing of a SAPV system using the intuitive method. Based on the records, the first application of intuitive technique was done in 1997 [93], where optimization of a SAPV system and tilt angle modules was done at five sites in Iran with different longitudes, latitudes and altitudes. First, the authors start optimizing the system by determining the optimum tilt angle between $0^{\circ}$ to $90^{\circ}$ for each sites, to maximize PV power generation. Then, PV array was chosen using the least PV size required to fulfil demand requirements, in order to minimize the cost. After that, by using statistical approach, number of successive cloudy days was decided. Based on that, battery size was determined, with expectation to fulfil demands during low intensity of solar radiation in cloudy days. However, this study only explains the PV and battery system sizing roughly without explanation of the modelling methods. Besides, the smallest PV array size was selected, and thus, it is very possible that the power generated by the system will be enough to supply the load, or unable to charge battery until having is enough charge to supply the load during cloudy days.

Afterwards in 2003, more detailed study was done using intuitive approach based on estimated monthly average of solar irradiation data in Dhaka, Bangladesh [94]. The researchers calculate array size by choosing a month with minimum solar radiation. Three designs of sizing methods to fulfil same daily load demands were developed and compared. In array sizing for first design, the authors first compared and choose a month with the worst peak sun hour (PSH) at tilt angle of site latitude, and tilt angle of $\pm 15^{\circ}$ to site latitude in summer and winter season. On the other hand, the second design's array sizing was done by manually chose worse radiation between $40^{\circ}$ and $10^{\circ}$ tilt angle with azimuth of $0^{\circ}$, and for third design, same method was applied for $40^{\circ}$ and $10^{\circ}$ tilt angle with azimuth of $\pm 45^{\circ}$. Then, the battery capacity chosen is assumed be able to supply 2 to 3 autonomy days. Lastly, the design with minimum array and battery size was selected as best design. Since the comparison has too many variables, an exclusive comparison between designs is defeasible.

Later, a more neat sizing was done in 2009 [95]. Solar irradiation data in Egypt for south facing PV array tilted by site latitude was used and considered as optimum tilt angle in that particular region. To fulfil an average daily demand for a household in remote area, PV array was sized with 
consideration of temperature correction factor, PV efficiency, battery efficiency and inverter efficiency. Intuitively, the authors modelled battery that competent to fulfil demand continuously for largest possible period of cloudy days. Later, they analysed system's life cycle cost to calculate unit generated cost for the proposed system. However, based on findings, the system may over sized, since energy price is very high as compared to typical electricity price in Egypt.

\subsection{Numerical Methods}

Numerical approach is the most frequently used in optimal sizing techniques for SAPV. In this category, the design was simulated for each time step within a period. SAPV energy balance and battery's state is calculated and investigated. This technique is offer adequate and comprehensive analysis. It is very accurate, but the calculation is complex and need more time for calculation and simulation. Besides, since there are different kinds of approaches or manners applied in these techniques, the comparison between studies under this method is inconsistent. As shown in Table 1, there are 20 studies use numerical methods to determine optimal configuration in SAPV. However, before 1997, there were five studies on numerical method done.

Optimization of tilt angle, PV size and battery storage using Greek Island's monthly average meteorological data size was presented in [69]. The optimum design was set to be the combination with lowest life cycle cost, in a predefined loss of energy probability. Number of battery bank replacements was determined using life cycle cost calculation. In [96], a simple technique for SAPV sizing was developed. This study used 23 years of hourly insolation data from 20 different sites in US to develop correlations between variability in insolation and average monthly horizontal insolation. Then, sizing nomograms that give array size as function of average horizontal insolation and storage capacity was generated as function of LOLP for long time interval. In [72], a computer aided program was developed to find optimum PV tilted angle, PV array size and battery storage. The authors predicted solar radiation model based on clear sky model. The difference between PV power generated and load demand was used to size battery capacity. Meanwhile, in [71], optimization of SAPV system was done by dividing the regions into four zone, based on sky clearness index characteristic. For a given LOLP, many combinations of battery capacity and PV array peak power were determined, and the system with lowest total cost is the best configuration. Afterwards, in 1996, optimal sizing method for SAPV was applied in Corsica [97]. Similar with [71], design with the lowest cost of energy is the optimum configuration to supply $1 \mathrm{kWh}$ load.

Shrestha G. et al. proposed new sizing method based on combination of PV panel sizing, battery storage sizing, charge regulator and load requirement in 1998 [73]. A stochastic model of PV generation was representing random behaviour of solar insolation. Required load demand also has been well defined in hourly basis. In this research, the system with minimum cost and minimum loss of load probability is the most favourable configuration. However, since the researchers used experimental load modelling, the LOLP and LOLH analysis are not too reliable.

Numerical code, named PHOTOV-III was presented to determine optimum configuration of SAPV system at Greece in 2004 [98]. The system objective is to operate in zero load rejections, with optimum tilt angle and minimum installation cost. In proposed system, hourly analysis using iterative technique to find all possible combinations of PV panel number and battery maximum size that able to perform zero load rejection operation. Then, based on analytical analysis, with minimum initial cost constraint, several alternatives were selected as possible optimum configuration. However, this method is not too convenience, since the possible configuration need to be selected manually.

A different simulation model for SAPV system sizing in Delhi with interconnection arrays was approached in 2005 [76]. For a predefined load, the optimum combinations of PV array and batteries for zero LOLP were calculated. Moreover, the authors compared fixed and tilted aperture arrays with single tracking aperture arrays, and simple system cost analysis was carried out on both systems.

In 2006 [99], a new sizing method was presented by using stochastic simulation for solar radiation. The proposed stochastic model is suitable to implement if original measured data is not available. 
For a given reliability index, energy balance using different pairs of PV array capacity and battery capacity was done to find the optimum combination. Reliability index was calculated using ratio of hours when load is satisfied over total simulation hours. The authors analysed fifteen different sites in Greece.

A. Fragaki proposed a new sizing approach using numerical method in [100], similar to her previous work in [101] by analytical method in 2008. This study constructed sizing curves for minimum PV generator capacity and battery storage, without losing the load. Minimum PV generation required was sized at least equal to load demand, by using the worst month daily radiation. Storage prerequisite for minimum generator size was calculated from minimum battery SOC for each year based on historical solar radiation data. However, this sizing method may cause oversizing, and the PV generated power may not fully used during high solar radiation energy period.

Other than that, Celik A. et al. presented optimum sizing method based on six years of meteorological data from five sites in Turkey [78]. Meanwhile, the authors obtained load profiles from five households in Turkey. The system performance simulated using hourly solar irradiation and ambient temperature data. The scheme was simulated iteratively, by increasing PV size gradually, while battery capacity is remained constant for five days storage capacity. Hourly energy generated flow in and out from battery and its state of charge was calculated. Then, the researchers constructed sizing curves after LOLP and LCC analysis, where they calculated LCC and cost payback time for three different LOLP values for each site in life cycle assessment.

Technical and economic analysis for SAPV system in Malaysia were done in 2008 [84], by using annual daily radiation data. There are two design variables contemplated, which are tilt angle and battery's dead of discharge (DOD). For a given load demand, maximum DOD, and preset LPSP, the best consolidation of PV size and battery size was calculated iteratively for several tilt angle values. The optimum tilt angle was chosen based on the lowest unit cost value. Then, for preset LPSP and chosen tilt angle, the same analysis was repeated using several DOD values.

The same author from [84] proposed new method for SAPV system sizing in 2009 [85]. This method implemented graphical approaches, where two graphs for a given LPSP was constructed, which are array size versus battery size, and partially differentiated of system cost function graph. The Tangent point of the graphs was the optimum size for PV array and battery. This method was much better compared to his previous work, since the most advantageous system was chosen based on graphical method, where the cost function was already minimized using partially derivation.

Arun P. et al. [33] presented chance constrained programming approach to solve uncertainty problem in solar radiation. For a specific energy source, demand, desired confidence level and system characteristic, a sizing curve for all possible combinations of photovoltaic array rating and storage capacity was plotted. Then, design space for feasible design was determined from the curve. Optimum configuration for a predefined reliability level was the combination with lowest cost of energy. As mention in [82], the limitation in this study is PV model prediction using deterministic approach was too simple, and cannot represent uncertainty in solar radiation [87]. Hence, it is better for future researchers to use time series meteorological data or another PV model prediction. Moreover, preset LOLP value used is considered high compared to other researches.

Askari I.B. et al. proffered an orderly optimal sizing method for PV array and battery system in Kerman, Iran, based on the site's hourly solar radiation data [86]. Panel's tilt angle is fixed as site latitude. For a given value of LPSP, PV module size and battery was determined iteratively. Then for a given value of LPSP, chart of PV modules versus hours of battery autonomy and its LCOE's graph was plotted, and combination with minimum LCOE was selected as optimum configuration.

Later, in 2010, the authors [87] presented an optimization using the stochastic method in equipment's characteristic data (PV modules, battery, and inverters), average temperature, solar radiation and load profile analysis. The optimization was done based on economic and reliability analysis, similar to [85]. For a given LPSP, the researchers established possible combinations for PV array size and battery storage size, and then they selected optimal combination with minimum cost 
by partially derivation of system cost equation. Moreover, the proposed method compared with deterministic method, and their merit and demerit was listed.

Mellit A. et al. has done several studies on SAPV sizing by employed artificial neural network (ANN). The studies was done in year 2005 [74], 2007 [77], and 2010 [81], in Algeria. In [74,77], The ANN model inputs were site's latitude and longitude, and the outputs were sizing factor of PV system and storage system. Then, in [81], the model was improved to four input; latitude, longitude, altitude and LOLP, and the output was PV array sizing factor. Storage sizing factor was calculated using mathematical equation.

\subsection{Analytical Methods}

In SAPV system sizing, the analytical method was used to obtain a close relation or correlation in a form of equation between capacities and reliabilities. From [34], usually there are three approaches applied, which are the probability-based approach, empirical coefficient determination, and application of novel methods, such as artificial neural networks (ANN). This technique allows designers to simplify their sizing methods into a representative equation, reduce calculation or computer process and the sizing procedure is more accurate. However, this method is not very popular because the constructed expression is not flexible. It is because the expression is very exclusive and restricted for specific sites. Moreover, it is hard to produce the relationship between capacities and reliabilities. The expression of system sizing also may have small errors compared to result from iterative sizing process.

Before 1997, there were five studies used analytical method to find optimum sizing in SAPV system. Three studies recorded in 1984, one in 1987 and the last one was in 1992. In [102], an analytical method was presented to predict fraction of energy load covered by PV generation system. The researchers attained sizing's coefficients value from simulation based on long term Italian meteorological data. However, this model leads to an oversized system. Meanwhile, a similar analytical procedure was proposed in [103]. Analysis was done based on monthly average solar insolation at Italian sites as well. However, Bartoli's model produce too low sensibility to battery size, as analyzed in [70].

Loss of load probability model was derived by two-event probability density function for difference of PV generated and load demand in [104]. Battery storage size calculation for a given array size was developed. The authors constructed analytical expressions for the probability of system storage needed and auxiliary energy required to cover demands in that event. The method then extended in [105], by taken account the effect of day-to-day insolation values. In [106], a similar method was used, but the authors extended it using three states model. In this study, analytical approaches based on stochastic theory were examined and recommended.

In 1992, a new analytical model was proposed based on meteorological data from three different locations in Spain [70]. An expression to relate array capacity, storage sized and LOLP was illustrated, with four different coefficient inputs, varies based on sites. Spain coefficient maps for two LOLP values were constructed to represent SAPV system sizing.

After a long absence, in 2005, the authors proposed an ANN-based methodology to obtain LOLP curves for SAPV system in Spain by using the Multilayer Perceptron (MLP) approach. In 2003 [107], the author presented the three layer MLP structure consist two input only, which is ratio of accumulator capacity over average daily load consumption and LOLP. Then, the structure was improved with addition of yearly clearness index, as the third input. Last layer has one node, which is ratio of generator capacity over average load consumption. The LOLP curves obtained in these researches was compared with real curves and curves developed in Instituto de Energia Solar Madrid in [70]. By using different methods and consideration of clearness index, the proposed curves was more fit to the real curves, and improvement can be seen compared to previous ones.

In 2006, a sizing procedure was proposed, where a curve was constructed using combination of several climatic cycles at low daily solar radiation [101]. The study used long term daily solar radiation from London, England. The procedure started with expressed array size equation and battery size's 
range equation, in term of constant load. PV array sized based on assumption there were no variation of solar radiation, and load could be supplied by array sized. Meanwhile, battery sized to be able to supply load in low solar radiation time interval. Then, both equations were combined and expressed in a sizing curve. The area above the graph is the feasible design region. Then, sizing curves for three of the most prominent climatic cycles was constructed, and then new smooth line was created based on curves' tangent. Unfortunately, this developed expression is only applicable in South East England. The system may be oversized or undersized, since the authors only considered three period of climatic cycle. It seems that the missing years are neglected because relatively high solar radiation and/or short climatic cycles.

There are two approaches for SAPV system sizing at 20 different locations in Spain proposed by the same authors in 2008 [79,80]. For both researches, the authors developed sizing curves, to predict LOLP, standard deviation of LOLP, failures, and standard deviation of failures, with a given tilt angle, predetermined PV generator capacity, and battery storage capacity in specific location. In [80], a new analytical analysis on daily energy balance analysis was proposed using variable monthly demand and tilt angle (varied based on season). Based on daily incident energy on tilted PV panel and daily storage state, LOLP and number of expected failures were calculated. Then LOLP's and failures' standard deviation were calculated. Meanwhile, compared to [79], the steps used was almost the same, but this technique consider monthly average clearness index in system analysis. Both studies analyzed relation between PV generation capacity, storage capacity and LOLP analysis. Nevertheless, the second paper has further analysis in dependence between PV generation capacity, LOLP, and storage capacity with daily radiation on tilted PV panel. However, the researchers did not conduct optimization in system sizing in both publications.

After a long absence, in 2012, the authors purposed an improved technique to present an inclusive sizing for standalone system for five locations in Malaysia [82]. By using iterative approach, two graphs were plotted to show relation of PV array sizes over LOLP, and relation between PV sizes and optimum battery sizes, based on average annual daily meteorological data. By MATLAB fitting toolbox, two formulas for optimum ratio of PV capacity and battery capacity over specific load value was derived. This research attained average coefficients for different five sites. From the finding, relation between ratios of PV generated capacity and load demand is exponential with LOLP, while relationship between PV capacity and battery capacity ratio over specific load demand is linear. However, as mentioned in [12], the limitation for the method used are the sizing was done based on daily solar meteorological energy and a constant value of daily load demand. Table 2 shows a summary of optimal sizing methods presented for SAPV. 
Table 2. Summary of SAPV optimal sizing methods.

\begin{tabular}{|c|c|c|c|c|c|}
\hline Year & Authors & Technique & Reliability Analysis & System Cost Analysis & Reference \\
\hline 1984 & Barra, L., et al. & Analaytical & & & [102] \\
\hline 1984 & Bartoli, B., et al. & Analaytical & & & [103] \\
\hline 1984 & Bucciarelli Jr, et al. & Analaytical & & & [104] \\
\hline 1986 & Bucciarelli Jr, et al. & Analaytical & & & [105] \\
\hline 1987 & Gordon, J. & Analaytical & & & [106] \\
\hline 1988 & Soras, C., et al. & Numerical & LOLP & LCC & [69] \\
\hline 1989 & Chapman, R.N. & Numerical & & & [96] \\
\hline 1992 & Egido, M., et al. & Analaytical & LOLP & & [70] \\
\hline 1995 & Elsheikh Ibrahim, et al. & Numerical & LOLP & & [72] \\
\hline 1995 & Hadj Arab, A., et al. & Numerical & LOLP & & [97] \\
\hline 1996 & Notton, G., et al. & Numerical & & LCOE & [97] \\
\hline 1997 & Samimi, J., et al. & Intuitive & & & [92] \\
\hline 1998 & Shrestha, G., et al. & Numerical & LOLP & & [73] \\
\hline 2003 & Bhuiyan, M., et al. & Intuitive & & & [94] \\
\hline 2004 & Kaldellis, J. & Numerical & & & [98] \\
\hline 2005 & Hontoria, L., et al. & Analaytical & LOLP & & [75] \\
\hline 2005 & Mellit, A., et al. & Numerical & LOLP & & [74] \\
\hline 2005 & Kaushika, N., et al. & Numerical & LOLP & & [76] \\
\hline 2006 & Markvart, T., et al. & Analaytical & & & [101] \\
\hline 2006 & Balouktsis, A., et al. & Numerical & & & [99] \\
\hline 2007 & Mellit, A., et al. & Numerical & LOLP & & [77] \\
\hline 2007 & Mellit, A., et al. & Numerical & LOLP & & [26] \\
\hline 2008 & Fragaki, A., et al. & Numerical & Others & & [100] \\
\hline 2008 & Celik, A., et al. & Numerical & LOLP & LCC & [78] \\
\hline 2008 & Weixiang, Shen. & Numerical & LPSP & LCC & [84] \\
\hline 2008 & Posadillo, R., et al. & Analaytical & LOLP & & [79] \\
\hline 2008 & Posadillo, R., et al. & Analaytical & LOLP & & [80] \\
\hline 2009 & Shen, W. & Numerical & LPSP & Others & [85] \\
\hline 2009 & Arun, P., et al. & Numerical & Others & & [33] \\
\hline 2009 & Askari, I.B., et al. & Numerical & LPSP & LCOE & [86] \\
\hline 2009 & Nafeh, A. & Intuitive & & LCC & [95] \\
\hline 2010 & Mellit, A. & Numerical & LOLP & & [81] \\
\hline 2010 & Cabral, C.V.T., et al. & Numerical & LPSP & Others & [87] \\
\hline 2012 & Khatib, T, et al. & Analaytical & LOLP & & [82] \\
\hline
\end{tabular}

\section{Grid Connected PV System Optimization Technique}

The system modelling for GCPV system can be the same as SAPV. Latest trend for GCPV optimum sizing is most research was done to find the optimum distribution of PV modules among inverter, and sizing within predefined space area (roof or land). However, GCPV size optimization methods cannot be categorized as SAPV. It is because most researches were done using artificial intelligence method, since in GCPV system sizing, there are many variables need to be optimized.

\subsection{Numerical Methods}

As mention in Section 5.2, numerical is a detail simulation is done within a period for each time step, where the calculation may become too complicated if there are too many variables to investigate. In 2005, design optimization of GCPV system on top of Federal Office Building in Carbondale [108] was presented. Optimum array size and array size was determined by maximizing array output energy, and minimizing electricity sold to grid. To evaluate ratio of energy generated used by building, the effectiveness ratio was considered. Effectiveness factor was defined as ratio of energy used from generated energy to supply load over total PV array output. Array size was determined using graph of electricity sold. The limitation of the proposed method is the authors choose the optimum PV and inverter size manually, without fine explanation for optimization criteria and inverter to PV sizing ratio.

In [2], numerical method was presented in 2013 to optimize PV system based on roof characteristics, either it is on flat or slightly tilted roof. The validation of developed simulation was done based on PVGIS, PVsyst and site measured data from several Swedish PV installations. Electricity generation profile was refined for all possible combinations constructed with different PV 
types, panel tilt angle, ground covering ratio, and azimuth. After evaluation of economical and physical aspects, optimum distribution under different conditions was found, and several alternatives were developed. This research also investigates three case studies, with different kind of roof characteristics. However, this study did not involve inverter-to-PV array sizing. Besides, the technique is very complicated, and need systematic calculations.

\subsection{Computer Aided Method}

Optimization sizing of GCPV system using computer aided design was implemented in 2006 [109]. The authors developed sizing strategies for PV installation by considering several economic issues as initial cost, payback periods and compensation of reactive energy. In modelling PV energy production, losses due to shading, conductors, tilted angle and orientation, and inverter efficiency were considered. Monthly energy generated and grid delivered power, fee, bill and income was analyzed. Many data variables were considered, which leads to a reliable results.

\subsection{Genetic Algorithm (GA)}

GA is an artificial intelligence technique (AI), which was inspired from evolution and inheritance trait in living organism. The algorithm imitates population's evolution, based on survival-of-the-fittest strategy. GA has three operations, which is selection, crossover and mutation. GA method has ability to derive global optimum solution with relative computational simplicity, including complicated problems with non-linear function or constraint. However, GA may suffer excessive complexity if the problem is too large [1].

In 2009 [22], the authors developed an optimum sizing method using genetic algorithm (GA) among list of commercial system devices (PV modules and inverters) in Microsoft Visual C++ software. The sizing process was started by selection of PV module and inverter model, available land area, climatic parameters, cost and economy parameters. The best number of PV modules, inverters, tilt angle, the best arrangement of PV modules among inverters, and optimum arrangement of PV modules within site area was elected based on maximum net economic profit as GA objective function. In this study, total net profit was maximised using NPC analysis, by considering total capital cost of PV modules, inverters, cost of land area, mounting structure cost, cost of installation, and maintenance cost. However, the researchers did not include inverter to PV array sizing ratio as one of optimization criteria. In addition, several power losses were not taken into account, such as temperature, dirt and cables. Moreover, the PV modules arrangement calculation is not suitable if the land area is not face to south.

In 2011 [25], a new sizing method was proposed to determine optimal PV modules and inverters by using GA. In this study, authors developed iterative sizing procedure as a benchmark to choose the best optimization methods between GA and evolutionary studies (ES). The proposed GCPV system capacity capable to fulfil energy requirement as specified by customer in $\mathrm{kWh}$ using preselect PV module model and inverter model. Peak Sun Hour at tilted panel angle, temperature reduction factor, manufacture's tolerance reduction factor, cable reduction factor, and inverter reduction factor was predefined was considered in sizing calculation. From possible PV modules arrangement among inverters, the highest value of inverter to array sizing factor and minimum excess factor was chosen as optimal design solution. From the methods comparison, GA method has lower percentage error compared to ES method.

In 2011, authors in [110] proposed optimization methods for large PV plant design using Greece's time series of one minute average solar radiation data. The researchers optimize the proposed system by maximizing energy production. From simulation, optimum PV module distribution, optimum PV rows, distance between rows and tilt angle was determined. Then, LCOE was analyzed for the optimal solution. The proposed method can only be used to design PV generation plant at fixed tilted panel mounted on South faced ground. PV distribution system among inverters and PV arrangement layout 
at predefined space area was done similar with methods in [22,111,112], except the inverter used in design are Central Inverter, Multi-string Inverter and Mini-Central Inverter.

In 2012, the same authors from [110] proposed a new optimization method for large PV plant in [113]. By using GA simulation, optimum PV module distribution, optimum PV rows, distance between rows and tilt angle was determined. However, the new technique was improved by including LCOE analysis within optimization process. The simulation result was compared to cases with non-optimized system, optimized for minimum cost only and optimized for maximum cost only.

An inclusive GA method presented in 2014, in [3] where the authors use all technical, economical and environmental criteria in their analysis. The authors developed their solar irradiance model using hourly average temperature and clearness index data Then PV model was developed to maximize energy output using field area restriction and design safety restriction, for predefined PV module model and inverter model characteristic. The PV layout design within space provided was optimized to reduce shading losses. Then, based on the configuration obtained from PV model, evaluation on economic, technical and environmental criteria was done. The authors used IMPACT2002++ for environment evaluation. All of the listed steps were conducted using five different types of PV panel technologies. The best configuration selection was based on weighted evaluation with 15 goals, which is maximizing energy output, minimizing payback time, minimizing energy payback time, and minimizing 12 environmental impacts.

\subsection{Particle Swarm Optimization (PSO)}

PSO is one of the metaheuristic methods using robust stochastic optimization technique based on the movement and intelligence of swarms. The technique applies concept of social interaction to problem solving. As mentioned in [111], PSO is easily programmed. Besides, the knowledge of good solution is retained and all particles able to share information between them. Meanwhile, in [112], multi-objectives was implemented, to allow optimization of two or more conflict objectives.

In 2010, Kornelakis, A., et al. developed two more optimization methods, based on particle swarm optimization (PSO) and multi-objectives particle swarm optimization technique [111,112], with several improvements compared to his previous proposed method in [22]. In [111], the authors compared his PSO-based findings with GA-based result in term of iterations. They have proved that by using PSO approach, the simulation time is shorter and lower number of iteration was obtained. Besides, GA was proved failed to locate several optimum solutions during optimisation process. In his later findings [112], environmental benefit was added in his optimization process as second objective function, while the decision variables is still the same. Particle swamp optimization was used to solve multi-objectives problem for purposed system. This technique was able to maximise both economic and environmental benefits in the system.

\subsection{Evolutionary Programming (EP)}

Similar to GA technique, EP also involves random process of selection, mutation and crossover in its operation. Individual fitness was defined in objectives function. EP evaluates behavioural connection between parents and offspring, with respect to similarities, differences and their performances [114].

In 2012 [4], Sulaiman, S.I., et al. proposed an optimization sizing with Evolutionary Programming Sizing Algorithm (EPSA). Unlike his previous method in [25], the optimization was able to test all available combination of PV and inverters in system database. The researchers implemented the same technique to determine optimal PV modules distributions among inverter. EPSA sizing was done using different EP modes with nonlinear step size scaling factor (NPSS), and the sizing results were compared. The proposed method can choose to optimize the system based on energy yield or net present value. Table 3 shows a summary of GCPV optimal sizing methods. 
Table 3. Summary of GCPV optimal sizing methods.

\begin{tabular}{ccccc}
\hline Year & Authors & Technique & System Cost Analysis & Reference \\
\hline 2005 & Gong, X., et al. & Numerical & Others & {$[108]$} \\
2006 & Fernández-Infantes, A., et al. & Evolutionary Programming & NPC & {$[109]$} \\
2009 & Kornelakis, A., et al. & GA & NPC & {$[22]$} \\
2010 & Kornelakis, A. & PSO & NPC & {$[111]$} \\
2010 & Kornelakis, A., et al. & Multi-Objective & NPC & {$[112]$} \\
2011 & Sulaiman, S.I., et al. & GA & & {$[25]$} \\
2011 & Kerekes, Tamas, et al. & GA & LCOE & {$[110]$} \\
2012 & Kerekes, T., et al. & GA & LCOE & {$[112]$} \\
2012 & Sulaiman, S.I., et al. & Evolutionary Programming & NPC & {$[4]$} \\
2013 & Näsvall, D. & Numerical & LCOE & {$[2]$} \\
2014 & Perez-Gallardo, J.R., et al. & GA & Others & {$[3]$} \\
\hline
\end{tabular}

\section{Sizing Constraint}

In PV system design, sometimes there are limitations or constraints that need to be explored. In past studies, available space, budget and energy demand are considered before the optimization of PV system design.

\subsection{Space Constraint}

Sometimes, customers give specific area to mount PV modules. In past years, several researchers included area as a constraint in their sizing. There are two types of area sizing for PV system, which are roof space's area constraint and land space area constraint. As referred in [108], optimization process for grid connected PV system on the rooftop of federal office building. In the study, array size and tilt angle are optimized, and the objectives for the model are to maximize array output energy as well as minimize electricity sold to grid.

Meanwhile, in [2,4], detailed sizing on top of roof was done based on PV module orientation. As shown in Figure 3, the roof space was used by choosing between two arrangements that can maximize panel's quantity on top of the roof, where $L$ is roof length, $W$ is roof width, $l$ is panel length, and $w$ is panel width.
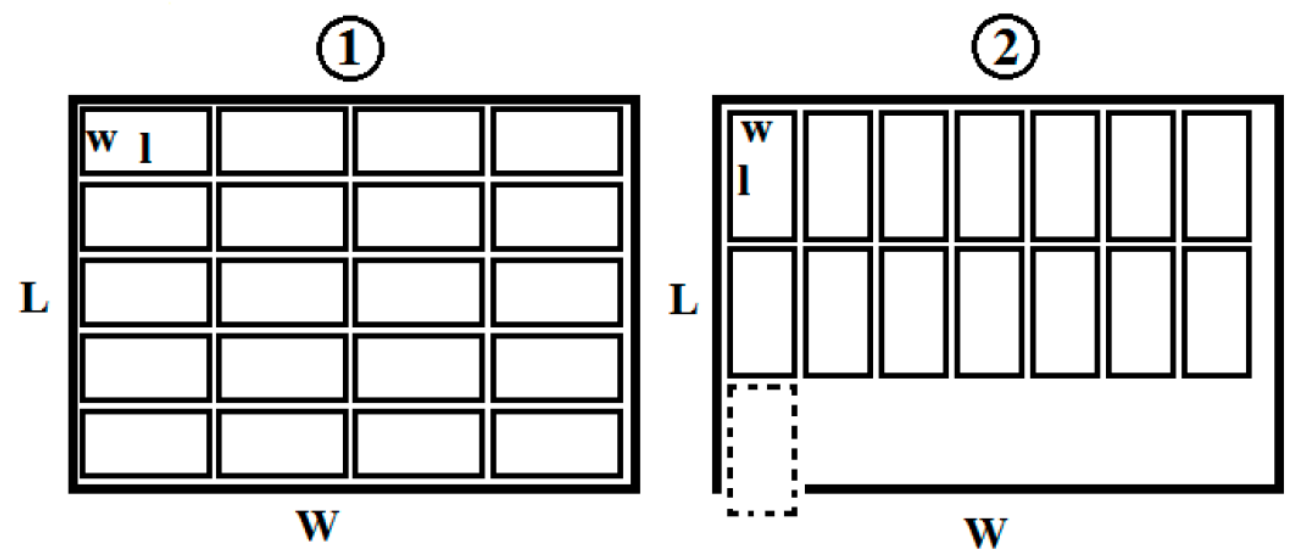

Figure 3. PV system layout options based on roof space constraint in system sizing [2].

Moreover, authors in [2] also proposed to consider PV system layout as shown in Figure 4, to allow PV panel mounted at optimum tilt angle on flat roof. Calculation was done to minimize shading losses while area was exploited at the same time, where $L$ is roof length, $W$ is panel width, and $\beta$ is module tilt angle. 


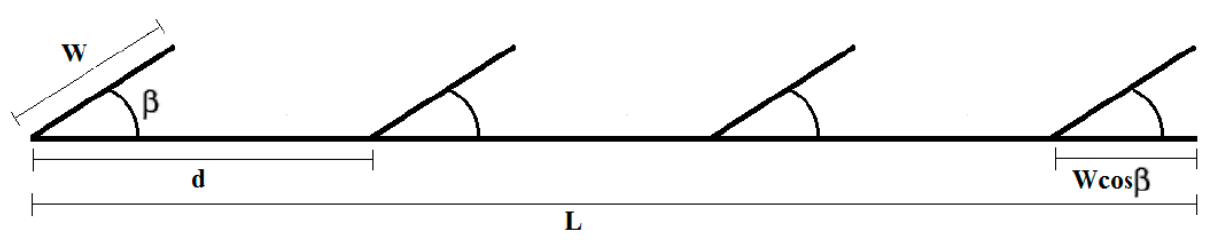

Figure 4. PV tilted system layout options based on roof space constraint in system sizing [2].

Several past studies [3,22,109-112] designed more complicated sizing in land space area, where PV modules tilt angle, maximum land space area, and shading effect was considered in order to find optimal arrangement of PV modules in the available installation area. The system layout is as shown in Figure 5 below, where $D$ is space between collector rows, $L_{c}$ is collector length, $H$ is collector height, $E_{\max }$ is limit of collector's height from ground, $\mathrm{W}$ is land width, $\beta$ is module tilt angle, $K$ is rows number, $L_{m}$ is module length, and $H_{m}$ is module width. However, this technique has limitation, where the researchers can only use the calculation and layout for land in south direction only.
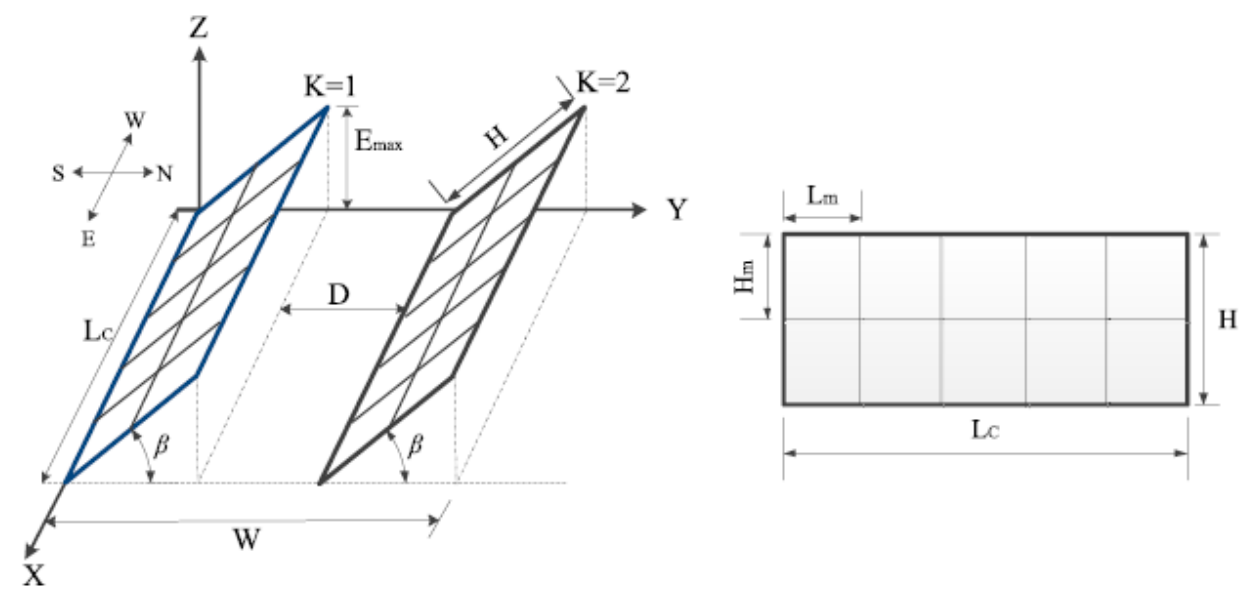

Figure 5. PV tilted system layout options based on land space constraint in system sizing [3].

\subsection{Budget Constraint}

In [109], a grid connected PV system was designed by considering economical element. The authors design a computer application to automatically calculate all relevant parameters in installation, such as physical, electrical, economical and ecological. The researchers included the limitation in installation budget during sizing process.

\subsection{Energy Constraint}

In most studies usually use one load profile as a reference or constraint in their sizing method. Energy constraint usually applied in standalone system, such as in [82,84-86]. However, grid connected system also can use electric load profile of the building for reference, as used in $[25,108]$. In both studies, researchers sized PV array based on energy required from customer. They selected optimal PV system based on minimization of difference between energy required and energy produced. Besides that, in $[79,80]$, an analytical method was done in sizing for standalone PV system with variable monthly demand. This demand was varied depend on season, monthly varies demand was use in system sizing and analysis.

However, other energy constraints have been considered recently such as a bidirectional power flow in PV system that contains normal electric vehicles (EV) or vehicle to grid EV $[115,116]$. Similarly having mechanical energy sources combined with the PV system may also affect the constraints such as in [117]. 


\section{Conclusions}

This paper provides a review on SAPV and GCPV systems sizing procedures, which are system components modelling, optimization software available, optimization criteria, optimization method, and sizing constraint. PV modelling and battery modelling is important in system sizing optimization, in order to predict system performances. Besides, by using a suitable optimization software package, the system process is express and simpler. Other than that, the most commonly used criteria in finding optimum solution for system sizing were investigated. For SAPV methods, only three optimal sizing methods were used for the past decades. Compared to GCPV system, even though the researches is not as many as SAPV, different optimization method was used in finding optimal sizing, including artificial intelligence (AI) methods, metaheuristic methods, and multi-objective (MO) design. System constraint is an optional process in PV system sizing, based on customer's requirements. Energy constraint was commonly used in SAPV sizing. In the other hand, past researches frequently employ space constraint in GCPV. According to the review in this paper, optimal sizing of proposed system is important as early step in PV system design. An accurate sizing may prevent oversize or undersize, which leads to development of high reliability system with low cost. Besides, AI and metaheuristic methods are suggested to be included in both SAPV and GCPV system to improve sizing process and optimization results in the future.

Funding: The authors would like to acknowledge funding from An-Najah National University grant No. ANNU-1819-Sc010.

Conflicts of Interest: The authors declare no conflict of interest.

\section{References}

1. Mellit, A.; Kalogirou, S.A. Artificial intelligence techniques for photovoltaic applications: A review. Prog. Energy Combust. Sci. 2008, 34, 574-632. [CrossRef]

2. Näsvall, D. Development of a Model for Physical and Economical Optimization of Distributed PV Systems. Master's Thesis, Uppsala University, Uppsala, Sweden, 2013.

3. Perez-Gallardo, J.; Azzaro-Pantel, C.; Astier, S.; Domenech, S.; Aguilar-Lasserre, A. Ecodesign of photovoltaic grid-connected systems. Renew. Energy 2014, 64, 82-97. [CrossRef]

4. Sulaiman, S.I.; Rahman, T.K.A.; Musirin, I.; Shaari, S.; Sopian, K. An intelligent method for sizing optimization in grid-connected photovoltaic system. Sol. Energy 2012, 86, 2067-2082. [CrossRef]

5. Zainuddin, H.; Shaari, S.; Omar, A.M.; Sulaiman, S.I. Power prediction for grid-connected photovoltaic system in Malaysia. In Proceedings of the 2011 3rd International Symposium \& Exhibition in Sustainable Energy \& Environment (ISESEE), Melaka, Malaysia, 1-3 June 2011; pp. 110-113.

6. Zhou, W.; Lou, C.; Li, Z.; Lu, L.; Yang, H. Current status of research on optimum sizing of stand-alone hybrid solar-wind power generation systems. Appl. Energy 2010, 87, 380-389. [CrossRef]

7. Eltawil, M.A.; Zhao, Z. Grid-connected photovoltaic power systems: Technical and potential problems-A review. Renew. Sustain. Energy Rev. 2010, 14, 112-129. [CrossRef]

8. Parida, B.; Iniyan, S.; Goic, R. A review of solar photovoltaic technologies. Renew. Sustain. Energy Rev. 2011, 15, 1625-1636. [CrossRef]

9. Baños, R.; Manzano-Agugliaro, F.; Montoya, F.; Gil, C.; Alcayde, A.; Gómez, J. Optimization methods applied to renewable and sustainable energy: A review. Renew. Sustain. Energy Rev. 2011, 15, 1753-1766. [CrossRef]

10. Khare, A.; Rangnekar, S. A review of particle swarm optimization and its applications in solar photovoltaic system. Appl. Soft Comput. 2013, 13, 2997-3006. [CrossRef]

11. Mellit, A.; Kalogirou, S.; Hontoria, L.; Shaari, S. Artificial intelligence techniques for sizing photovoltaic systems: A review. Renew. Sustain. Energy Rev. 2009, 13, 406-419. [CrossRef]

12. Khatib, T.; Mohamed, A.; Sopian, K. A review of photovoltaic systems size optimization techniques. Renew. Sustain. Energy Rev. 2013, 22, 454-465. [CrossRef]

13. Lalwani, M.; Kothari, D.; Singh, M. Investigation of solar photovoltaic simulation softwares. Int. J. Appl. Eng. Res. 2010, 1, 585-601. 
14. Sinha, S.; Chandel, S. Review of software tools for hybrid renewable energy systems. Renew. Sustain. Energy Rev. 2014, 32, 192-205. [CrossRef]

15. Khatib, T.; Mohamed, A.; Sopian, K. A review of solar energy modeling techniques. Renew. Sustain. Energy Rev. 2012, 16, 2864-2869. [CrossRef]

16. Demain, C.; Journée, M.; Bertrand, C. Evaluation of different models to estimate the global solar radiation on inclined surfaces. Renew. Energy 2013, 50, 710-721. [CrossRef]

17. Duffie, J.A.; Beckman, W.A. Solar Engineering of Thermal Processes; John Wiley \& Sons: Hoboken, NJ, USA, 2013.

18. Noorian, A.M.; Moradi, I.; Kamali, G.A. Evaluation of 12 models to estimate hourly diffuse irradiation on inclined surfaces. Renew. Energy 2008, 33, 1406-1412. [CrossRef]

19. Abdulkadir, M.; Samosir, A.; Yatim, A. Modeling and Simulation based Approach of Photovoltaic system in Simulink model. ARPN J. Eng. Appl. Sci. 2012, 7.5, 616-623.

20. Rus-Casas, C.; Aguilar, J.; Rodrigo, P.; Almonacid, F.; Pérez-Higueras, P. Classification of methods for annual energy harvesting calculations of photovoltaic generators. Energy Convers. Manag. 2014, 78, 527-536. [CrossRef]

21. Sera, D.; Teodorescu, R.; Rodriguez, P. PV panel model based on datasheet values. In Proceedings of the 2007 IEEE International Symposium on Industrial Electronics, Vigo, Spain, 4-7 June 2007; pp. 2392-2396.

22. Kornelakis, A.; Koutroulis, E. Methodology for the design optimisation and the economic analysis of grid-connected photovoltaic systems. IET Renew. Power Gener. 2009, 3, 476-492. [CrossRef]

23. Nema, P.; Nema, R.; Rangnekar, S. A current and future state of art development of hybrid energy system using wind and PV-solar: A review. Renew. Sustain. Energy Rev. 2009, 13, 2096-2103. [CrossRef]

24. Khatib, T.; Mohamed, A.; Sopian, K.; Mahmoud, M. Optimal sizing of the energy sources in hybrid PV/diesel systems: A case study for Malaysia. Int. J. Green Energy 2013, 10, 41-52. [CrossRef]

25. Sulaiman, S.I.; Rahman, T.K.A.; Musirin, I.; Shaari, S. Sizing grid-connected photovoltaic system using genetic algorithm. In Proceedings of the 2011 IEEE Symposium on Industrial Electronics and Applications, Langkawi, Malaysia, 25-28 September 2011; pp. 505-509.

26. Mellit, A.; Benghanem, M.; Kalogirou, S.A. Modeling and simulation of a stand-alone photovoltaic system using an adaptive artificial neural network: Proposition for a new sizing procedure. Renew. Energy 2007, 32, 285-313. [CrossRef]

27. Mellit, A.; Kalogirou, S.A. ANFIS-based modelling for photovoltaic power supply system: A case study. Renew. Energy 2011, 36, 250-258. [CrossRef]

28. Sonnenenergie, D.G.F. Planning and Installing Photovoltaic Systems: A Guide for Installers, Architects and Engineers; Earthscan: Oxford, UK, 2008.

29. Huang, B.; Hsu, P.; Wu, M.; Ho, P. System dynamic model and charging control of lead-acid battery for stand-alone solar PV system. Sol. Energy 2010, 84, 822-830. [CrossRef]

30. Zahedi, A. Development of an electrical model for a PV/battery system for performance prediction. Renew. Energy 1998, 15, 531-534. [CrossRef]

31. Li, J.; Wei, W.; Xiang, J. A Simple Sizing Algorithm for Stand-Alone PV/Wind/Battery Hybrid Microgrids. Energies 2012, 5, 5307-5323. [CrossRef]

32. Piller, S.; Perrin, M.; Jossen, A. Methods for state-of-charge determination and their applications. J. Power Sources 2001, 96, 113-120. [CrossRef]

33. Arun, P.; Banerjee, R.; Bandyopadhyay, S. Optimum sizing of photovoltaic battery systems incorporating uncertainty through design space approach. Sol. Energy 2009, 83, 1013-1025. [CrossRef]

34. Arun, P.; Banerjee, R.; Bandyopadhyay, S. Sizing curve for design of isolated power systems. Energy Sustain. Dev. 2007, 11, 21-28. [CrossRef]

35. Arun, P.; Banerjee, R.; Bandyopadhyay, S. Optimum sizing of battery-integrated diesel generator for remote electrification through design-space approach. Energy 2008, 33, 1155-1168. [CrossRef]

36. Urtasun, A.; Sanchis, P.; Barricarte, D.; Marroyo, L. Energy management strategy for a battery-diesel stand-alone system with distributed PV generation based on grid frequency modulation. Renew. Energy 2014, 66, 325-336. [CrossRef]

37. Khatib, T.; Elmenreich, W. Novel simplified hourly energy flow models for photovoltaic power systems. Energy Convers. Manag. 2014, 79, 441-448. [CrossRef] 
38. Weniger, J.; Tjaden, T.; Quaschning, V. Sizing of Residential PV Battery Systems. Energy Procedia 2014, 46, 78-87. [CrossRef]

39. Gitizadeh, M.; Fakharzadegan, H. Battery capacity determination with respect to optimized energy dispatch schedule in grid-connected photovoltaic (PV) systems. Energy 2014, 65, 665-674. [CrossRef]

40. Parra, D.; Walker, G.S.; Gillott, M. Modeling of PV generation, battery and hydrogen storage to investigate the benefits of energy storage for single dwelling. Sustain. Cities Soc. 2014, 10, 1-10. [CrossRef]

41. Achaibou, N.; Haddadi, M.; Malek, A. Modeling of lead acid batteries in PV systems. Energy Procedia 2012, 18, 538-544. [CrossRef]

42. Badescu, V. Dynamic model of a complex system including PV cells, electric battery, electrical motor and water pump. Energy 2003, 28, 1165-1181. [CrossRef]

43. Badescu, V. Time dependent model of a complex PV water pumping system. Renew. Energy 2003, 28, 543-560. [CrossRef]

44. Cherif, A.; Jraidi, M.; Dhouib, A. A battery ageing model used in stand alone PV systems. J. Power Sources 2002, 112, 49-53. [CrossRef]

45. Stein, J.S.; Hansen, C.W.; Cameron, C.P. Evaluation of PV Performance Models and Their Impact on Project Risk; Sandia National Laboratories: Albuquerque, NM, USA, 2010.

46. Menicucci, D.F.; Fernandez, J. Users Manual for PVFORM: A Photovoltaic System Simulation Program for Stand-Alone and Grid-Interactive Applications; Sandia National Labs: Albuquerque, NM, USA, 1989.

47. INSEL-The Graphical Programming Language for the Simulation of Renewable Energy Systems. Available online: http:/ / www.insel.eu/ (accessed on 23 February 2018).

48. Klise, G.T.; Stein, J.S. Models Used to Assess the Performance of Photovoltaic Systems; Report SAND2009-8258; Sandia National Laboratories: Albuquerque, NM, USA, 2009.

49. Klein, S.A.E.A. TRNSYS 17: A Transient System Simulation Program. Available online: http://sel.me.wisc. edu/trnsys (accessed on 23 February 2010).

50. Shandilya, K.K.; Kumar, A. Available energy assessment software. Environ. Prog. Sustain. Energy 2013, 32, 170-175. [CrossRef]

51. HOMER Software. Available online: http://www.homerenergy.com/ (accessed on 23 February 2018).

52. Natural Resources Canada. Available online: http://www.retscreen.net/ang/g_photo.php (accessed on 23 February 2018).

53. Naional Renewable Energy Laboratory. Available online: https://sam.nrel.gov/ (accessed on 23 February 2018).

54. Gilman, P.; Dobos, A. SAM 2011.12. 2: General Description. Contract 2012, 303, 275-3000.

55. Marion, B.; Anderberg, M. PVWATTS-An Online Performance Calculator for Grid-Connected PV Systems. In Proceedings of the Solar Conference, Madison, WI, USA, 16-21 June 2000; pp. 119-124.

56. Marion, B.; Anderberg, M.; Gray-Hann, P. Recent Revisions to PVWATTS: United States; Department of Energy: Washington, DC, USA, 2005.

57. Mermoud, A. PVSYST Version 3.2. User's Manual; University of Geneva, University Center for the Study of Energy Problems: Geneva, Switzerland, 2002; Available online: http:/ / www.pvsyst.com/ (accessed on 1 December 2002).

58. PVsyst: Software for Photovoltaic System. Available online: http://www.pvsyst.com/en/ (accessed on 23 February 2018).

59. Details of PVSOL Experts. Available online: http:/ /www.valentin.de/ (accessed on 23 February 2018).

60. SolarPro. Available online: http://www.lapsys.co.jp/english/products/pro.html (accessed on 23 February 2018).

61. F-Chart Software. Available online: http://www.fchart.com/fchart/ (accessed on 23 February 2014).

62. SolarDesignTool. Available online: http://get.solardesigntool.com/feature/pv-solar-system-design/ (accessed on 23 February 2014).

63. Maui Solar Energy Software Corporation Products. Available online: http://www.mauisolarsoftware.com/ (accessed on 23 February 2014).

64. Dufo-López, R. iHOGA; Electrical Engineering Department, University of Zaragoza: Zaragoza, Spain, 2012.

65. Khatib, T.; Mohamed, A.; Sopian, K. A Software Tool for Optimal Sizing of PV Systems in Malaysia. J. Model. Simul. Eng. 2012, 2012, 969248. [CrossRef] 
66. Pochacker, M.; Khatib, T.; Elmenreich, W. The Microgrid Simulation Tool RAPS: Description and Case Study. In Proceedings of the 2014 IEEE Innovative Smart Grid Technologies Conference-Asia (ISGT ASIA), Kuala Lumpur, Malaysia, 20-23 May 2014.

67. Huld, T.; Suri, M. PVGIS, PV Estimation Utility. 2010. Available online: http://re.jrc.ec.europa.eu/pvgis / apps4/pvest.php (accessed on 23 February 2018).

68. About SolarGIS. Available online: http://solargis.info/doc/ (accessed on 29 September 2018).

69. Soras, C.; Makios, V. A novel method for determining the optimum size of stand-alone photovoltaic systems. Sol. Cells 1988, 25, 127-142. [CrossRef]

70. Egido, M.; Lorenzo, E. The sizing of stand alone PV-system: A review and a proposed new method. Sol. Energy Mater. Sol. Cells 1992, 26, 51-69. [CrossRef]

71. Arab, A.H.; Driss, B.A.; Amimeur, R.; Lorenzo, E. Photovoltaic systems sizing for Algeria. Sol. Energy 1995, 54, 99-104. [CrossRef]

72. Ibrahim, O.E.E. Sizing stand-alone photovoltaic systems for various locations in Sudan. Appl. Energy 1995, 52, 133-140. [CrossRef]

73. Shrestha, G.; Goel, L. A study on optimal sizing of stand-alone photovoltaic stations. IEEE Trans. Energy Convers. 1998, 13, 373-378. [CrossRef]

74. Mellit, A.; Benghanem, M.; Arab, A.H.; Guessoum, A. An adaptive artificial neural network model for sizing stand-alone photovoltaic systems: Application for isolated sites in Algeria. Renew. Energy 2005, 30, 1501-1524. [CrossRef]

75. Hontoria, L.; Aguilera, J.; Zufiria, P. A new approach for sizing stand alone photovoltaic systems based in neural networks. Sol. Energy 2005, 78, 313-319. [CrossRef]

76. Kaushika, N.; Gautam, N.K.; Kaushik, K. Simulation model for sizing of stand-alone solar PV system with interconnected array. Sol. Energy Mater. Sol. Cells 2005, 85, 499-519. [CrossRef]

77. Mellit, A.; Benghanem, M. Sizing of stand-alone photovoltaic systems using neural network adaptive model. Desalination 2007, 209, 64-72. [CrossRef]

78. Celik, A.; Muneer, T.; Clarke, P. Optimal sizing and life cycle assessment of residential photovoltaic energy systems with battery storage. Prog. Photovolt. Res. Appl. 2008, 16, 69-85. [CrossRef]

79. Posadillo, R.; Luque, R.L. Approaches for developing a sizing method for stand-alone PV systems with variable demand. Renew. Energy 2008, 33, 1037-1048. [CrossRef]

80. Posadillo, R.; Luque, R.L. A sizing method for stand-alone PV installations with variable demand. Renew. Energy 2008, 33, 1049-1055. [CrossRef]

81. Mellit, A. ANN-based GA for generating the sizing curve of stand-alone photovoltaic systems. Adv. Eng. Softw. 2010, 41, 687-693. [CrossRef]

82. Khatib, T.; Mohamed, A.; Sopian, K.; Mahmoud, M. A new approach for optimal sizing of standalone photovoltaic systems. Int. J. Photoenergy 2012, 2012, 391213. [CrossRef]

83. Yang, H.; Zhou, W.; Lu, L.; Fang, Z. Optimal sizing method for stand-alone hybrid solar-wind system with LPSP technology by using genetic algorithm. Sol. Energy 2008, 82, 354-367. [CrossRef]

84. Weixiang, S. Design of standalone photovoltaic system at minimum cost in Malaysia. In Proceedings of the 2008 3rd IEEE Conference on Industrial Electronics and Applications, Singapore, 3-5 June 2008; pp. $702-707$.

85. Shen, W. Optimally sizing of solar array and battery in a standalone photovoltaic system in Malaysia. Renew. Energy 2009, 34, 348-352. [CrossRef]

86. Askari, I.B.; Ameri, M. Optimal sizing of photovoltaic-Battery power systems in a remote region in Kerman, Iran. Proc. Inst. Mech. Eng. Part A J. Power Energy 2009, 223, 563-570. [CrossRef]

87. Cabral, C.V.T.; Diniz, A.S.A.C.; Martins, J.H.; Toledo, O.M.; Neto, L.D.V.B.M. A stochastic method for stand-alone photovoltaic system sizing. Sol. Energy 2010, 84, 1628-1636. [CrossRef]

88. Bilal, B.O.; Sambou, V.; Ndiaye, P.; Kebe, C.; Ndongo, M. Multi-objective design of PV-wind-batteries hybrid systems by minimizing the annualized cost system and the loss of power supply probability (LPSP). In Proceedings of the 2013 IEEE International Conference on Industrial Technology (ICIT), Cape Town, South Africa, 25-28 February 2013; pp. 861-868.

89. Yang, H.; Wei, Z.; Chengzhi, L. Optimal design and techno-economic analysis of a hybrid solar-wind power generation system. Appl. Energy 2009, 86, 163-169. [CrossRef]

90. Park, C.S.; Kumar, P.; Kumar, N. Fundamentals of Engineering Economics; Pearson/Prentice Hall: Upper Saddle River, NJ, USA, 2004. 
91. Kamel, S.; Dahl, C. The economics of hybrid power systems for sustainable desert agriculture in Egypt. Energy 2005, 30, 1271-1281. [CrossRef]

92. Applasamy, V. Cost evaluation of a stand-alone residential photovoltaic power system in Malaysia. In Proceedings of the 2011 IEEE Symposium on Business, Engineering and Industrial Applications (ISBEIA), Langkawi, Malaysia, 25-28 September 2011; pp. 214-218.

93. Samimi, J.; Soleimani, E.A.; Zabihi, M. Optimal sizing of photovoltaic systems in varied climates. Sol. Energy 1997, 60, 97-107. [CrossRef]

94. Bhuiyan, M.; Asgar, M.A. Sizing of a stand-alone photovoltaic power system at Dhaka. Renew. Energy 2003, 28, 929-938. [CrossRef]

95. Nafeh, A. Design and Economic Analysis of a stand-alone PV system to electrify a remote area household in Egypt. Open Renew. Energy J. 2009, 2, 33-37. [CrossRef]

96. Chapman, R.N. Development of sizing nomograms for stand-alone photovoltaic/storage systems. Sol. Energy 1989, 43, 71-76. [CrossRef]

97. Notton, G.; Muselli, M.; Poggi, P.; Louche, A. Autonomous photovoltaic systems: Influences of some parameters on the sizing: Simulation timestep, input and output power profile. Renew. Energy 1996, 7, 353-369. [CrossRef]

98. Kaldellis, J. Optimum technoeconomic energy autonomous photovoltaic solution for remote consumers throughout Greece. Energy Convers. Manag. 2004, 45, 2745-2760. [CrossRef]

99. Balouktsis, A.; Karapantsios, T.; Antoniadis, A.; Paschaloudis, D.; Bezergiannidou, A.; Bilalis, N. Sizing stand-alone photovoltaic systems. Int. J. Photoenergy 2006, 2006, 73650. [CrossRef]

100. Fragaki, A.; Markvart, T. Stand-alone PV system design: Results using a new sizing approach. Renew. Energy 2008, 33, 162-167. [CrossRef]

101. Markvart, T.; Fragaki, A.; Ross, J. PV system sizing using observed time series of solar radiation. Sol. Energy 2006, 80, 46-50. [CrossRef]

102. Barra, L.; Catalanotti, S.; Fontana, F.; Lavorante, F. An analytical method to determine the optimal size of a photovoltaic plant. Sol. Energy 1984, 33, 509-514. [CrossRef]

103. Bartoli, B.; Cuomo, V.; Fontana, F.; Serio, C.; Silvestrini, V. The design of photovoltaic plants: An optimization procedure. Appl. Energy 1984, 18, 37-47. [CrossRef]

104. Bucciarelli, L.L., Jr. Estimating loss-of-power probabilities of stand-alone photovoltaic solar energy systems. Sol. Energy 1984, 32, 205-209. [CrossRef]

105. Bucciarelli, L.L., Jr. The effect of day-to-day correlation in solar radiation on the probability of loss-of-power in a stand-alone photovoltaic energy system. Sol. Energy 1986, 36, 11-14. [CrossRef]

106. Gordon, J. Optimal sizing of stand-alone photovoltaic solar power systems. Sol. Cells 1987, 20, $295-313$. [CrossRef]

107. Hontoria, L.; Aguilera, J.; Zufiria, P. A tool for obtaining the LOLP curves for sizing off-grid photovoltaic systems based in neural networks. In Proceedings of the 3rd World Conference onPhotovoltaic Energy Conversion, Osaka, Japan, 11-18 May 2003; pp. 2423-2426.

108. Gong, X.; Kulkarni, M. Design optimization of a large scale rooftop photovoltaic system. Sol. Energy 2005, 78, 362-374. [CrossRef]

109. Fernández-Infantes, A.; Contreras, J.; Bernal-Agustín, J.L. Design of grid connected PV systems considering electrical, economical and environmental aspects: A practical case. Renew. Energy 2006, 31, 2042-2062. [CrossRef]

110. Kerekes, T.; Koutroulis, E.; Eyigun, S.; Teodorescu, R.; Katsanevakis, M.; Sera, D. A practical optimization method for designing large PV plants. In Proceedings of the 2011 IEEE International Symposium on Industrial Electronics, Gdansk, Poland, 27-30 June 2011; pp. 2051-2056.

111. Kornelakis, A.; Marinakis, Y. Contribution for optimal sizing of grid-connected PV-systems using PSO. Renew. Energy 2010, 35, 1333-1341. [CrossRef]

112. Kornelakis, A. Multiobjective Particle Swarm Optimization for the optimal design of photovoltaic grid-connected systems. Sol. Energy 2010, 84, 2022-2033. [CrossRef]

113. Kerekes, T.; Koutroulis, E.; Sera, D.; Teodorescu, R.; Katsanevakis, M. An Optimization Method for Designing Large PV Plants. IEEE J. Photovolt. 2012, 3, 814-822. [CrossRef] 
114. Bäck, T.; Rudolph, G.; Schwefel, H.-P. Evolutionary programming and evolution strategies: Similarities and differences. In Proceedings of the Second Annual Conference on Evolutionary Programming, La Jolla, CA, USA, 25-26 February 1993.

115. Morshed, M.J.; Hmida, J.B.; Fekih, A. A Probabilistic Multi-Objective Approach for Power Flow Optimization in hybrid Wind-PV-PEV Systems. Appl. Energy 2018, 211, 1136-1149. [CrossRef]

116. Islam, M.S.; Mithulananthan, N. PV based EV charging at universities using supplied historical PV output ramp. Renew. Energy 2018, 118, 306-327. [CrossRef]

117. Azizipanah-Abarghooee, R.; Niknam, T.; Bina, M.A.; Zare, M. Coordination of combined heat and power-thermal-wind photovoltaic units in economic load dispatch using chance constrained and jointly distributed random variables methods. Energy 2015, 79, 50-67. [CrossRef]

(c) 2018 by the authors. Licensee MDPI, Basel, Switzerland. This article is an open access article distributed under the terms and conditions of the Creative Commons Attribution (CC BY) license (http://creativecommons.org/licenses/by/4.0/). 